\title{
Levels, Trends, and Health Effects of Dioxins and Related Compounds in Aquatic Biota
}

\author{
Jianwen She, Ho Sai Simon Ip, Yufeng Guan, Da Chen, Hyo-Bang Moon, \\ Anna Roos, Dongli Wang, JianQing Zhang, Michelle L. Berger, \\ and Susan D. Shaw
}

\author{
J. She and H.S.S. Ip \\ California Department of Public Health, Environmental Health Laboratory Branch, Richmond, \\ CA 94804, USA \\ Y. Guan \\ California Department of Public Health, Environmental Health Laboratory Branch, Richmond, \\ CA 94804, USA
}

School of Chemistry and Environment, South China Normal University, Guangzhou 510006, China

D. Chen

Cooperative Wildlife Research Laboratory and Department of Zoology, Southern Illinois

University Carbondale, Carbondale, IL 62901, USA

H.-B. Moon

Department of Environmental Marine Science, College of Science and Technology, Hanyang University, Ansan, Republic of Korea

\footnotetext{
A. Roos

Swedish Museum of Natural History, Department of Environmental Contaminant Research, Box 50007, 10405 Stockholm, Sweden

D. Wang

Food and Drug Branch, California Department of Public Health, Richmond, CA 94804, USA

J. Zhang

Shenzhen Center for Disease Control and Prevention, Shenzhen 518020, China

M.L. Berger

Marine and Environmental Research Institute, P.O. Box 1652, 55 Main Street, Blue Hill, ME 04614, USA

S.D. Shaw $(\bowtie)$

Marine and Environmental Research Institute, P.O. Box 1652, 55 Main Street, Blue Hill, ME 04614, USA

Department of Environmental Health Sciences, School of Public Health, State University of New York at Albany, P.O. Box 509, Albany, NY 12201-0509, USA

e-mail: sshaw@meriresearch.org
} 


\begin{abstract}
The objective of this chapter is to review current knowledge of the levels, trends, and health effects of dioxins and dioxin-like compounds (DLCs) including polychlorinated dibenzo- $p$-dioxins and dibenzofurans (PCDD/Fs), polybrominated dibenzo- $p$-dioxins and dibenzofurans (PBDD/Fs), and polychlorinated biphenyls (PCBs) in aquatic biota, with a special focus on high trophic level species. DLCs can be released into the environment through storm runoff, air deposition, wastewater discharge from industrial processes, and leaching from landfills. To characterize their influences in biota, studies examining levels and trends of DLCs from invertebrates to vertebrates from several regions (the Arctic, North America, Asia and Europe) are reviewed. Over several decades, such studies have helped elucidate the accumulation, possible sources, metabolic fate, as well as the potential health effects of dioxins and DLCs in aquatic biota. The trophic transfer of these compounds via bioaccumulation and biomagnification can result in higher concentrations in top predators, and a wide range of toxic effects (e.g., endocrine disruption, developmental and reproductive effects, and immunotoxicity) has been reported in diverse species, especially those occupying high trophic levels, e.g., marine mammals. Because of their high trophic position and widespread distribution, marine mammals are valuable sentinel species for PCB and DLC contamination, providing insights into possible sources, transport pathways, and the distribution of these compounds on a global scale. Populationlevels effects related to contaminant-induced reproductive impairment and disease have been reported in wildlife inhabiting polluted regions, and the occurrence of mass mortalities among marine mammal populations has been linked to high body burdens of immunotoxic compounds, notably PCBs. Many affected populations have never recovered to their original levels. For many contaminant-stressed populations, the added stress of climate change is exacerbating the problem, causing shifts in food webs and increasing both the distribution and toxicity of POPs in coastal and oceanic environments. Critical data gaps and future research challenges are highlighted as areas that require further study.
\end{abstract}

Keywords Aquatic biota, Brominated dibenzo- $p$-dioxins and dibenzofurans, Chlorinated dibenzo- $p$-dioxins and dibenzofurans, Climate change, Dioxin-like PCBs, Immunotoxicity, Marine mammals, Mass mortalities, Polychlorinated biphenyls, Trophic transfer

\title{
Contents
}

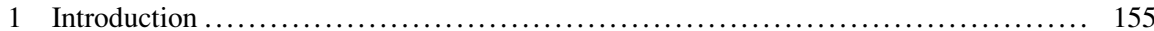

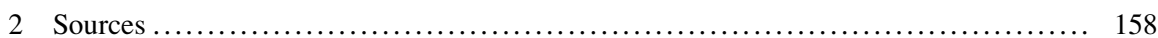

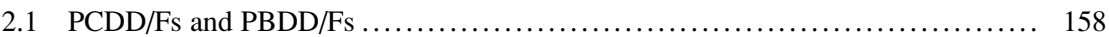

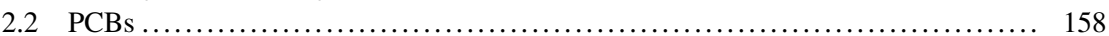

3 Levels and Trends in Aquatic Biota ........................................ 159

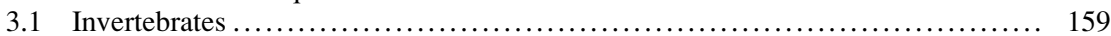

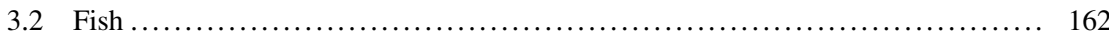

3.3 Turtles .......................................................... 164 


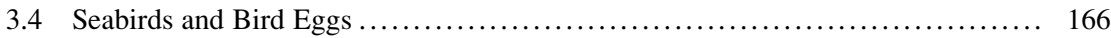

3.5 Marine Mammals ................................................. 171

4 Health Effects and Risk .................................................. 177

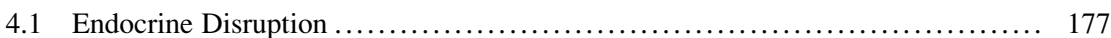

4.2 Developmental/Reproductive Effects ................................. 179

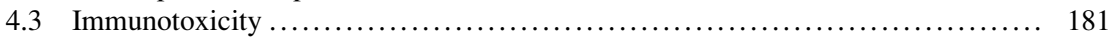

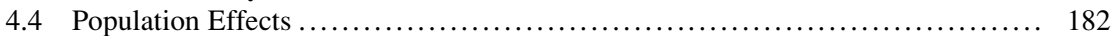

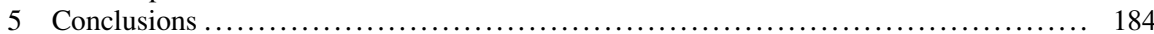

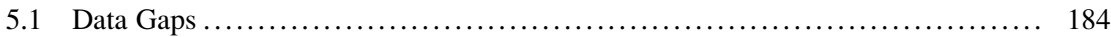

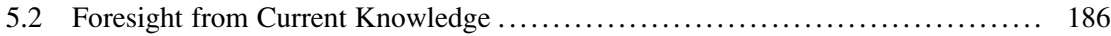

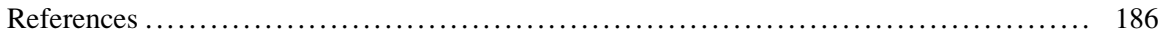

\section{Introduction}

The environmental and human health implications of dioxins and dioxin-like compounds (DLCs) have been of ongoing concern since the mid-1980s. "Dioxins" generally refers to 75 congeners of polychlorinated dibenzo- $p$-dioxins (PCDDs) and 135 congeners of dibenzofurans (PCDFs). Seventeen of these 210 PCDD/Fs congeners have chlorine atoms in the 2, 3, 7, and 8 positions of the molecular structure and exhibit high toxicity [1]. Twelve of the 209 polychlorinated biphenyl (PCBs) congeners, with a similar stereostructure to PCDD/Fs, i.e., PCB-77, -81, $-105,-114,-118,-123,-126,-156,-157,-167,-169$, and -189 , are known as dioxinlike PCBs (dl-PCBs) or DLCs. These 29 compounds can be bound to the aryl hydrocarbon receptor (AhR) and induce the AhR-mediated toxic responses. They also were among the first group of compounds to be included in the toxic equivalency factors (TEFs) scheme by the World Health Organization (WHO) in 1997 [1]. The most toxic congener 2,3,7,8-tetrachlorodibenzo- $p$-dioxin (TCDD) is used as a reference congener in the TEF scheme with a TEF value defined as 1 , and the toxicity of other dioxins and DLC was assigned a value in between 0 and 1 relative to 2,3,7,8-TCDD's TEF. The concepts of TEFs and toxic equivalent (TEQ) concentrations have been introduced to facilitate risk assessments and the regulatory control of dioxin and DLC exposure [1,2]. Later on, in 2011, a joint WHO and United Nations Environment Programme (UNEP) expert panel evaluated and extended the TEF scheme of dioxin-like compounds to include polybrominated dibenzo- $p$-dioxins (PBDDs), polybrominated dibenzofurans (PBDFs), and certain dioxin-like polybrominated biphenyls (PBBs) [3]. A detailed review of the validity and criteria for inclusion in the TEF concept was recently completed [2, 3]. Although there are a large number of other halogenated compounds (e.g., polychloronaphthalenes, polybrominated naphthalenes, mixed halogenated dibenzo- $p$ dioxins, mixed halogenated dibenzofurans, hexachlorobenzene, and polychloroterphenyls, among others) which meet the inclusion criteria for the TEF scheme, they are not included herein due to the lack of environmental and toxicological data. The chemical structures of PCDD/Fs, PBDD/Fs, PCBs, and related compounds are shown in Fig. 1. 


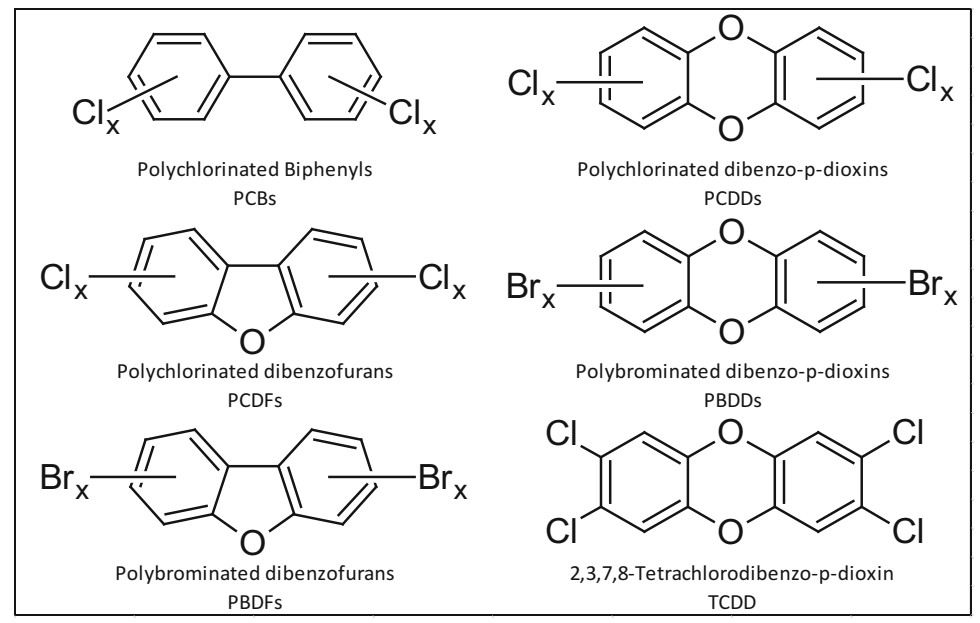

Fig. 1 Structures of dioxin and dioxin-like halogenated compounds

PCDDs and PCDFs are released into the environment from different combustion processes [4-7], and are sometimes present in various chlorinated chemical formulations as byproducts or impurities [8-10]. These compounds can be produced by a wide range of manufacturing processes such as incineration and iron ore sinter plants, as well as from accidental fires. Among the different emission sources, higher levels can be produced by waste treatment processes that use incinerators without proper emission controls [11, 12]. PBDDs and PBDFs have been found in combustion gases (processes) and combustion engines [13-15], and may occur as impurities in commercial PBDE (polybrominated diphenyl ether) mixtures $[16$, 17]. Large amounts of PBDD/Fs may be formed during fires under uncontrolled combustion conditions in the presence of PBDEs [15, 18-20]. In contrast to the unintended generation of dioxins, PCBs were manufactured for industrial usage and they were typically released from the application or disposal of industrial PCB-containing products. Although the domestic production of PCBs was banned in 1979, PCBs are still used in closed systems such as transformers, capacitors, and other electrical equipment. Four decades later, PCBs can still be detected in the air, water, sediments, soil, and biota. Most PCBs in water are bound to particulates and sediments, and are slowly released over a long period of time (decades). Because of their stability and ongoing inputs, PCBs are subject to recycling in food webs and will remain an environmental concern for the foreseeable future [21].

Because of their lipophilic nature and resistance to metabolism, PCBs, dioxins, and related compounds bioaccumulate and biomagnify in the fatty tissues of animals and humans. PCBs can easily reach higher concentrations in predator species at the upper trophic levels $[22,23]$ and are the predominant contaminants in most wildlife populations today [24, 25]. High levels of dioxins and PCBs have been detected in dolphins [26-28], harbor seals (Phoca vitulina) [25, 29, 30], 
northern fur seals (Callorhinus ursinus) [31], hooded seals (Cystophora cristata) [32], Steller sea lions (Eumetopias jubatus) [33], sharks [27, 34], predatory birds [28, 35], and human tissues [28, 36-38]. Toxic responses to DLCs including immunotoxicity, endocrine disruption, and adverse effects on reproduction and development have been observed in diverse species of biota [39-42]. A large amount of data suggests that PCBs and DLCs have adversely affected the health of marine mammals [40, 41, 43-45], and are associated with endocrine-disrupting effects, immune suppression, infertility, skeletal abnormalities, and population declines among seals from the North and Baltic Seas [44, 46-49]. PCBs are also associated with a high prevalence of neoplasms and carcinoma that cause mortality in California sea lions (Zalophus californianus) [50]. Reproductive effects resulting in declines in otter (Lutra lutra) populations in Europe have been linked to high concentrations of OC contaminants, notably PCBs [44, 51-53].

PCBs and PCDD/Fs have long been suspected to play a role in the recurring epizootics and large-scale mortalities among marine mammals, including US Atlantic coast harbor seals $[54,55]$ and bottlenose dolphins (Tursiops truncatus) [56]; seals in the Baltic and North Seas [57, 58]; Mediterranean striped dolphins (Stenella coeruleoalba) [59-61]; Baikal seals (Phoca sibirica) [62]; and Caspian seals (Phoca caspica) [63], among others. Feeding studies conducted in the mid-1980s and 1990s demonstrated the sensitivity of harbor seals to PCB and $\mathrm{PCDD} / \mathrm{F}$ exposure and helped establish a threshold level for PCB-related toxic effects in adult marine mammals. Harbor seals fed PCDD/F and PCB-contaminated fish exhibited reproductive impairment [48], reduced plasma thyroid hormone and retinol levels [64], and the suppression of numerous cellular and humoral immune functions $[65,66]$. Recent biomarker studies indicate that nursing seal pups with relatively low blubber concentrations of PCBs may be vulnerable to immune- and endocrine disrupting effects during a sensitive window of development [25, 67-70].

The study of temporal trends for PCBs, dioxins, and other DLCs in biota is useful to aid policy makers in developing effective regulatory policies for the protection of public health and the environment. Trend studies provide information that places current environmental inputs and chemical loading into context and helps in the assessment of potential future impacts. This chapter provides an overview of levels, trends, and health effects of PCDD/Fs, PBDD/Fs, and PCBs in aquatic species from invertebrates to vertebrates from different regions, including phytoplankton, zooplankton, shellfish, fish, turtles, seabirds, and marine mammals. Knowledge gaps and potential future research perspectives are highlighted. 


\section{Sources}

\subsection{PCDD/Fs and PBDD/Fs}

$\mathrm{PCDD} / \mathrm{Fs}$ and PBDD/Fs are the byproducts of many industrial and combustion processes. Social and scientific concerns regarding PCDD/Fs increased with the detection of TCDD in Agent Orange [71], the herbicide that was widely used during the Vietnam War [71, 72]. Three mechanisms for the formation of PCDD/Fs during incineration have been proposed. These mechanisms include the input of wastes containing unburned PCDD/Fs, combustion processes in the presence of precursors (chlorinated compounds) of PCDD/Fs, and de novo synthesis [73-77]. In accordance with the Stockholm Convention, the USA, Canada, Australia, Japan, and certain European countries have performed nationwide surveys to create an emission inventory of PCDD/Fs in the atmosphere from 1993 to 1997, and these data were intended to identify the potential emission sources of PCDD/Fs [78]. The major emission source of $\mathrm{PCDD} / \mathrm{F}$ is waste incineration, including municipal, hazardous, and industrial types, which accounted for $69 \%$ of the total PCDD/F emissions to the atmosphere. The next highest contributors to the total emissions of PCDD/Fs are the combustion process of iron and steel (10\%) and non-ferrous metal processing (8\%). Other emission sources of PCDD/Fs are chloralkali processes, the bleaching of pulp and paper, the burning of chlorine-containing fuels, and the production of pentachlorophenols [78-85].

PBDD/Fs are also unintentional by-products of incineration processes, and they have similar physico-chemical properties and anthropogenic sources as PCDD/Fs [86]. An important source of $\mathrm{PBDD} / \mathrm{F}$ is the incineration of products containing BFRs and the thermolysis of BFR material, e.g., PBDEs during fire events [1820]. PBDD/Fs can also be formed during thermal processing procedures of PBDEs such as polyeurethane foam extrusion, molding and recycling, and degradation $[19,86,87]$ and ultra-violet irradiation of deca-BDE [88]. Additionally, PBDD/Fs are found at trace levels as impurities in commercial BFR products, such as DE-71, DE-79, DE-83, and some deca-BDE products [16, 17, 89].

\section{$2.2 \quad P C B s$}

From 1929 until their prohibition in 1979, PCBs were in widespread use as closed systems and heat transfer fluids, hydraulic fluids and lubricants, plasticizers, and fire retardants [9]. Over five decades, the USA was responsible for approximately half of the world's production of PCBs and imported 50\% of the PCBs produced by other countries [90]. PCBs are still authorized for use in many applications [9]. Fresh sources of PCBs include in-service electrical equipment, transformers, machinery, manufacturing sites, building materials, landfills and scrap yards, and waste and recycling operations, many of which are located in densely populated 
urban/industrial centers [9, 91]. Because of evidence of adverse health effects in wildlife and humans, PCB production and use was banned by most developed countries in the late 1970s. However, approximately 1.5 million metric tons were produced worldwide in addition to 650,000 metric tons in the USA, and large volumes of $\mathrm{PCBs}$ are still contained in transformer equipment and landfills [92]. Incomplete combustion and industrial processes are also an important source of PCBs [93, 94]. Emerging evidence suggests that non-legacy PCBs are unintentionally present in pigments used for dyes, inks, and paints [95]. It was estimated by the late 1980 s that only about $1 \%$ of all PCBs had reached the oceans, while about $30 \%$ had accumulated in dumpsites and sediments of rivers, coastal zones, and estuaries [96]. Because of fresh inputs (from current permitted uses) and vast environmental reservoirs, PCBs are expected to remain the predominant contaminants in aquatic and marine biota at least until 2050 [21].

\section{Levels and Trends in Aquatic Biota}

\subsection{Invertebrates}

Understanding the accumulation of dioxins and DLCs in phytoplankton is essential for assessing the occurrence, transport, and distribution of these contaminants in aquatic environments. Phytoplankton uptake influences the fate and transport of pollutants since it is a key step in the transfer of pollutants from water to fish [9799]. In addition, phytoplankton uptake and the subsequent transfer to zooplankton result in depositional fluxes of organic pollutants in underlying aquatic environments [100].

Joiris and Overloop [101] determined the concentrations of PCBs in phytoplankton and zooplankton that were collected from the Indian sector of the Southern Ocean in 1987. The PCB concentration in netplankton $(200 \mu \mathrm{m}$ mesh size, primarily zooplankton) was $0.35 \mu \mathrm{g} / \mathrm{g}$ dry weight (dw) or $5.8 \mu \mathrm{g} / \mathrm{g} \mathrm{lw}$, which was about half of that measured in phytoplankton $(0.74 \mu \mathrm{g} / \mathrm{g} \mathrm{dw})$ on a dry weight basis and about a third of the phytoplankton level $(16.3 \mu \mathrm{g} / \mathrm{g}$ lw) on a lipid weight basis. The difference between phytoplankton and zooplankton was even more extreme when reported on a water volume basis thereby emphasizing the need for consistent units when comparing studies. The PCB levels in this study were similar to those found in North Sea zooplankton $(0.7 \mu \mathrm{g} / \mathrm{g} \mathrm{dw})$ [102]. Galbán-Malagón et al. [103] recently reported the concentrations of PCBs and other organochlorines in seawater and phytoplankton from the Southern Ocean during their Antarctic cruises in 2005, 2008, and 2009. The PCB concentrations in phytoplankton from this study ranged from 0.0027 to $0.014 \mu \mathrm{g} / \mathrm{g} \mathrm{dw}$ which was $1-2$ orders of magnitude lower than the 1987 study. The long-term decreasing trends in PCB levels were also found in seawater from the Southern Ocean, with a half-life of 5.7 years. 
Seawater and planktonic copepods (Calanus glacialis and C. hyperboreus) were collected from the Alaskan and Canadian Arctic regions to investigate the spatial distribution and bioaccumulation of organochlorines (OCs) such as PCBs [104]. The PCB concentrations in Alaskan and western Canadian zooplankton (12.6-33.8 ng/g dw) were comparable to those from northern Baffin Bay (30.2 $\mathrm{ng} / \mathrm{g} \mathrm{dw}$ ) but lower than those from Rankin Inlet in central Canada (54.5 ng/g dw).

Okumura et al. [105] reported the bioaccumulation of PCDD/Fs and dl-PCBs in lower trophic level organisms collected from Sendai Bay, Japan. The total concentrations of PCDDs, PCDFs, and dl-PCBs in phytoplankton were 150, 12, and $51 \mathrm{pg} /$ $\mathrm{g}$ wet weight $(\mathrm{ww})$, respectively. The $\mathrm{PCDD} / \mathrm{F}$ concentrations in zooplankton (which are primary consumers) were lower than the levels in phytoplankton (a primary producer), but the dl-PCBs concentrations in zooplankton were higher than the levels in phytoplankton thereby indicating a difference in bioaccumulation between PCDD/Fs and dl-PCBs at the lowest trophic levels.

Wan et al. [106] reported PCDD/Fs and PCBs in a marine food web including the phytoplankton and zooplankton collected from Bohai Bay, China. The concentrations of PCDD/Fs were $28.9 \mathrm{pg} / \mathrm{g}$ ww $(0.50 \mathrm{pg}$ TEQ $/ \mathrm{g} \mathrm{ww})$ in phytoplankton and $18 \mathrm{pg} / \mathrm{g}$ ww (0.32 pg TEQ/g ww) in zooplankton. Dl-PCB concentrations were 57.8 and $8.4 \mathrm{pg} / \mathrm{g}$ ww $(0.50$ and $0.32 \mathrm{pg} \mathrm{TEQ} / \mathrm{g} \mathrm{ww})$ in phytoplankton and zooplankton, respectively.

Peltonen et al. [107] reported the concentrations of PCDDs, PCDFs, and PCBs in offshore zooplankton (size from 0.2 to $20 \mathrm{~mm}$ ) collected in 2001, 2002, and 2010 from the northern and central Baltic Sea. Concentrations of PCDD/Fs were 10.1$21.7 \mathrm{pg} / \mathrm{g}$ lw $\mathrm{WHO}_{2005}$-TEQ in 2001/2002 and were 7.2-19.3 pg/g lw $\mathrm{WHO}_{2005^{-}}$ TEQ in 2010. Among the PCDD/Fs, the most toxic congeners 2,3,7,8-TCDD, 1,2,3,7,8-PeCDD, 2,3,7,8-TCDF, and 2,3,4,7,8-PeCDF contributed above $80 \%$ of the total toxicity of PCDD/Fs. PCB concentrations were $6.0-12.9 \mathrm{pg} / \mathrm{g} \mathrm{lw}$ $\mathrm{WHO}_{2005}$-TEQ in 2001/2002 and were 3.7-9.1 pg/g lw $\mathrm{WHO}_{2005}$-TEQ in 2010 and few temporal differences were noticed. However, 1,2,3,4,6,7,8-HpCDF and OCDF were found to predominate in 2001-2002, especially in the eastern Gulf of Finland (average concentrations 50 and 89 pg/g lw, respectively). The PCB concentrations were highest in the Gulf of Finland and in the Bothnian Bay, and concentrations of most PCBs were somewhat higher in 2001-2002 than in 2010. Among the dioxin-like PCBs, the concentrations of PCB-77 were highest (271$572 \mathrm{pg} / \mathrm{g} \mathrm{lw}$ ), followed by PCB-126 (32-113 pg/g lw), PCB-169 (5.81-25.5 pg/g lw).

Dynamic bioaccumulation models for these contaminants have been developed by researchers through field surveys of dioxins and DLCs in plankton [98, 108]. Dachs et al. [108] developed dynamic models that couple air-water exchange and the phytoplankton uptake of POPs and then applied them to field PCB measurements. The simulation results suggested that air-water exchange and other atmospheric-derived inputs primarily contribute to the POP concentrations in phytoplankton. In addition, this process suggested a major role in the global cycling 
of POPs, with POP atmospheric deposition considered a major contamination source for the world's oceans.

Shellfish are useful sentinel species for studying levels and trends of contaminants in aquatic environments. Diaz [109] measured dioxins in shellfish from the Oakland Bay in Washington State, USA and found that the dioxin concentrations in Manila clams ranged from 0.05 to $0.27 \mathrm{pg} / \mathrm{g} \mathrm{lw}$, which were similar to those in Pacific oysters (0.13-0.37 pg/g lw), and lower than those in Kumamoto oysters (0.3-0.6 pg/g lw). In mussels, total dioxin concentration was about $0.17 \mathrm{pg} / \mathrm{g}$ lw. Parera et al. [110] analyzed PCDDs, PCDFs, and PCBs in marine shellfish (murex, carpet shell, and mussel) of the Ebro River Delta, Spain and found that PCDD/F concentrations were $0.29-1.17 \mathrm{pg} / \mathrm{g} \mathrm{ww}$, and the concentrations of dl-PCBs were 24.6-399 pg/g ww. PCDFs contributed a larger content to WHO-TEQ $_{2005}$ extent than PCDDs. A slight decrease of PCDD/F and dl-PCB concentrations was noticed from 2006 to 2012, which was in agreement with the decrease in PCDD/F and PCB concentrations observed in human serum in Spain [111]. The levels of PCDDs, PCDFs, and PCBs for 123 Spanish commercial oyster, mussel, and clam samples from 1995 to 2003 were determined and there was a significant decrease of dioxin and dl-PCB concentrations since 1995. The decrease of dioxin levels was more obvious than that of dl-PCBs, especially during the early years of the study [112]. Munschy et al. [113] evaluated the levels and temporal trends of PCDD/Fs in archived marine mussels collected between 1981 and 2005 from selected sites along French coasts and noticed a pronounced decrease in $\mathrm{PCDD} / \mathrm{F}$ concentrations over the 24-year period at most sites, except Toulon on the Mediterranean Sea.

In 2005, PBDDs were identified and reported in blue mussels from the Baltic Sea [114], and the concentration of total triBDD was estimated to be $170 \mathrm{ng} / \mathrm{g} \mathrm{lw}$ [114]. Haglund et al. [115] measured PBDDs in marine fish, mussels, and shellfish from the Bothnian Bay and Bothnian Sea, the West Coast of Sweden, and the Baltic Proper. They found that the levels of PBDDs were higher in mussels than in other species, and there was an increasing temporal trend of PBDDs in mussels with an average annual increase of $11 \%$ from 1995 to 2003 [115]. Mussels, oysters, and scallops in Scotland were analyzed for PCDD/Fs, PBDD/Fs, PCBs, and other compounds [116]. PBDFs predominated over brominated dioxins. Generally, mussels and oysters had relatively higher levels of contamination than scallops, and their levels of contamination in the Southern beaches were greater than those in the north and northwest, which was consistent with Scottish industrial activity levels [116]. Fernandes et al. [117] also investigated PBDD/Fs in Pacific oysters (Crassostrea gigas), native oysters (Ostrea edulis), mussels (Mytilus edulis), scallops (Pecten maximus), and cockles (Cerastoderma edule) collected between 2006 and 2007 in the UK. PBDFs were detected more frequently and generally at a higher level than PBDDs. Oysters and mussels displayed relatively higher levels of PBDD/Fs. The levels of PBDD/Fs were consistent with the extent of local industrialization with lower levels observed in more remote areas such as the north of Scotland [117]. 


\subsection{Fish}

Monitoring environmental levels and trends of contaminants in fish is useful for studies of contamination levels and patterns in aquatic ecosystems, and for assessing potential health risks associated with wildlife and human consumption [118]. Kiviranta et al. [119] analyzed Baltic herring samples caught from the Baltic Sea during the spring periods of 1993-1994 and 1999 for PCDD/Fs and PCBs. Concentrations of some PCDD/F congeners and some PCB congeners in herring measured in 1993-1994 in the Gulf of Finland showed a clear correlation with the age of herring, which is consistent with the bioaccumulation of PCDD/Fs and PCBs. The PCDD/F concentrations ranged from 1 to $27 \mathrm{pg}$ TEQ/g ww, and PCB concentrations reached $32 \mathrm{pg} \mathrm{TEQ} / \mathrm{g}$ ww. No clear downward concentration trend of PCDD/Fs and PCBs in herring was observed between 1993 and 1994 and 1999. Karl et al. [120] determined PCDD/F and dl-PCB levels in the muscle of herring collected in 2006 and compared them with their previous study conducted at the same location in 1999 from the Western and Central Baltic Sea. The results from the 2006 study showed that PCDD/Fs and dl-PCBs of all herring samples were found to be below the maximum and action levels, and the average concentration was $3.55 \mathrm{pg}$ TEQ/g ww. The comparison between 2006 and 1999 did not reveal obvious change in contamination levels during the 7-year time period. Similarly, $\mathrm{PCDD} / \mathrm{F}$ and dl-PCB concentrations in Baltic herring (Clupea harengus) from the Swedish coast were found to be relatively stable since the mid to late 1990s; however, a general decreasing trend was seen for $\mathrm{TEQ}_{2005}$ PCDD, PCDF, and dl-PCB values at all sites, especially in the southern Bothnian Sea since 2001 [121]. It is unknown why concentrations in Baltic herring are not following the decreasing trend observed in other environmental matrices [121]. In Finland, altogether 344 samples of Baltic herring from 1978 to 2009 were collected across the Finnish coast of the Baltic Sea [122]. During the 31-year period, PCDD/F and PCB concentrations decreased about $80 \%$, from 20 to $5 \mathrm{pg}$ TEQ/g ww. The current concentrations of $\mathrm{PCDD} / \mathrm{Fs}$ and $\mathrm{PCBs}$ in Baltic herring are relatively low, and mostly below EU maximum accepted levels, and are expected to continue decreasing [122].

Haglund et al. [115] determined PBDDs in marine fish from the Bothnian Bay and Bothnian Sea, the West Coast of Sweden, and the Baltic Proper. The levels of PBDDs in littoral fish generally exceeded those of PCDDs in Baltic Proper. Recently, Haglund et al. [123] reported the PBDDs in perch (Perca fluviatilis) from a Baltic Sea background contaminated area between 1990 and 2005. Although no temporal trend was found, large variations of PBDD concentrations were observed between consecutive years. Ashizuka et al. [124] measured PBDD/Fs in fish samples from three regions in Japan. 1,2,3,4,6,7,8-HpBDF was the most abundant congener of PBDFs with concentrations of $0.10-25.6 \mathrm{pg} / \mathrm{g} \mathrm{ww}$.

Bordajandi et al. [125] determined PCDD/Fs and PCBs in edible fish, namely wedge sole (Dicologoglossa cuneata), common sole (Solea vulgaris), white seabream (Diplodus sargus), sardine (Sardina pilchardus), and angler fish (Lophius 
piscatorius) from the Coast of Huelva, on the Spanish southwest Atlantic coast. Total PCB concentrations were $861-23,787 \mathrm{pg} / \mathrm{g}$ ww, while 2,3,7,8-PCDD/Fs concentrations ranged from 0.2 to $1.18 \mathrm{pg} / \mathrm{g}$ ww. PCDD/F concentrations ranged from 0.038 to $0.186 \mathrm{pg} \mathrm{TEQ} / \mathrm{g}$ ww, values well below the maximum concentrations established by the EU. PCBs contributed most to the total TEQ content in most species studied. Gómara et al. [112] also investigated PCDD/F and PCB content of 123 Spanish commercial salmon, tuna fish, and sardine samples from 1995 to 2003. A significant decrease in dioxin and non-ortho PCB concentrations was found over the years. The decrease was greater for dioxins than for non-ortho PCBs, especially during the early years of the study. The high contribution of PCBs to total WHO-TEQs in the fish species investigated suggests that it is important to monitor PCBs in fish products, and they should be included in further research and future legislation [112]. Parera et al. [110] reported the concentration trends of PCDD/F and dl-PCBs during 2006-2012 in marine fish in the Ebro River Delta area (Spain) and found that the concentrations of $\mathrm{PCDD} / \mathrm{Fs}$ and dl-PCBs ranged from 0.03 to $0.31 \mathrm{pg} \mathrm{TEQ} / \mathrm{g}$ ww and from 0.02 to $3.15 \mathrm{pg} \mathrm{TEQ} / \mathrm{g}$ ww, respectively. All levels were below the maximum concentrations established by the EU Regulation. A slight decreasing trend in the levels of PCDD/F and dl-PCBs in fish was found from 2006 to 2012.

Hickey et al. [126] updated earlier reports with data from 1991 to 1998 for lake trout (Salvelinus namaycush) (Lake Erie only) and walleye (Sander vitreus) from the Great Lakes and quantified contaminant trends using multi-compartment models. As found in the past, fish from Lakes Michigan, Ontario, and Huron had the highest levels of PCBs. In the period after curtailment of chemical use, concentrations rapidly decreased, due to their relatively short half-lives from approximately 1 to 9 years. For dioxin-like PCBs, levels have not been decreasing during the 5-year period (1994 to 1998) [126]. Bhavsar et al. [127] measured concentrations of the seventeen 2,3,7,8-PCDD/Fs in lake trout (S. namaycush) or lake whitefish (Coregonus clupeaformis) collected in 1989-2003 from the Canadian Great Lakes. 2,3,7,8-TCDD, 2,3,7,8-TCDF, 1,2,3,7,8-PeCDD, 1,2,3,7,8PeCDF, and 2,3,4,7,8-PeCDF were the most dominant congeners. The highest TEQs were from Lake Ontario lake trout $(22-54 \mathrm{pg} / \mathrm{g})$ while the TEQs for the other Canadian Great Lakes were $60-95 \%$ lower. A linearly decreasing trend for PCDD/Fs in lake trout from Lakes Ontario and Huron was found. There was no monotonously increasing or decreasing trend found for Lake Superior lake trout.

Brown et al. [128] measured PCDD/Fs and dl-PCBs in fish collected from San Francisco Bay in 2000 and from the California coast in 2001. The samples were composites of only the edible portions of the fish (skin on, skin off, or whole body minus head and guts) of comparable size and from distinct geographical areas. For all fish of all species, the mean PCDD/F was $33.1 \mathrm{pg} T E Q / \mathrm{g}$ lw. The mean for PCB-77, -126, and -169 was $109 \mathrm{pg}$ TEQ/g lw. The highest concentrations of PCDD/F and dl-PCBs were found in the highly populated areas of San Francisco Bay, the Los Angeles area, and San Diego Bay. 


\subsection{Turtles}

Snapping turtles (Chelydra serpentina) have been commonly used to evaluate the extent of organic chemical contamination and trends in the Great Lakes [129-139] and the Hudson River of New York [140,141] since the 1970s. Snapping turtle eggs are also excellent bioindicators of the health conditions in wetlands and the bioavailability of organic contaminants. Snapping turtle eggs provide comprehensive information concerning the temporal and spatial trends of PCDD/Fs and PCBs [134, 136, 139]. Bonin et al. [142] compared the OCP and PCB levels in 39 snapping turtle clutches collected from ten sites along a highly polluted stretch of the St. Lawrence River in Canada. The results showed a high inter-site variability in PCB concentrations, which was consistent with those found by Bishop et al. [130] and Struger et al. [139]. De Solla et al. [135] reported a significant correlation between PCB concentrations in snapping turtle eggs and the industrial use of specific technical PCB mixtures in these areas. Hong et al. [143] reported the occurrence of planar, mono- and di-ortho PCBs in the fat tissues of snapping turtles that were collected in 1988 from rivers in the USA. The highest concentrations of PCBs $(1,010 \mu \mathrm{g} / \mathrm{g} \mathrm{ww})$ and TEQs $(106,000 \mathrm{pg}$ TEQ/g ww) were found in snapping turtles from the Grasse River in northern New York, where extensive PCB and PCDF contamination was associated with the aluminum industry. Relatively higher PCBs $(258 \mu \mathrm{g} / \mathrm{g} \mathrm{ww})$ and TEQs $(47,000 \mathrm{pg}$ TEQ/g ww) were also found in snapping turtles from the Snye Marsh of the St. Lawrence River, which is contaminated by large point sources. Dabrowska et al. [132] measured the TEQ concentrations of dl-PCBs in the fat tissue, eggs, and plasma of snapping turtles from the Ohio Basin of Lake Erie, USA. The TEQ concentrations, which were based on mammalspecific TEFs, ranged from 1.4 to $6.9 \mathrm{pg} / \mathrm{g}$ ww and from 21 to $582 \mathrm{pg} / \mathrm{g}$ ww in plasma and eggs, respectively. Significant correlations were found for PCB concentrations among fat tissues, eggs, and plasma from snapping turtles.

In comparison with PCBs, few studies are available on the PCDD/F concentrations in snapping turtle eggs or tissues. Most studies have reported the predominance of 2,3,7,8-TCDD for PCDDs and 2,3,4,7,8-PeCDF and 2,3,7,8-TCDF for PCDFs in snapping turtle eggs, depending on various factors such as the metabolism and the specific source of these contaminants [129, 134, 139]. Similar to the occurrence of PCDD/F congeners in eggs, the fat and liver tissues of snapping turtles from the St. Lawrence River, USA, were also dominated by 2,3,7,8-TCDD and 2,3,4,7,8-PeCDF [137].

Sea turtles are relatively sedentary, long-lived reptiles containing large fat bodies for POP accumulation [143-146]. Although known to be robust to physical damage, sea turtles are surprisingly very susceptible to chemical contaminants [147]. Following a long (10-year) open-water pelagic developmental phase, juvenile turtles settle in near-shore environments and forage on seagrass and algae close to land-based contaminant sources. All seven species of marine turtles worldwide are currently threatened or endangered, thus, sea turtles are important bioindicators of the levels and trends of chemical contamination in near-shore marine biota 
[145, 146, 148-152]. Keller et al. [145] investigated PCBs and OCPs and their possible health effects on loggerhead sea turtles (Caretta caretta) from Core Sound, North Carolina by associating their concentrations with clinical health assessment data, including hematology, plasma chemistry, and body condition. They found that PCBs and other OC contaminants might affect the health of loggerhead sea turtles even though sea turtles, with an herbivorous diet, tend to accumulate lower concentrations of POPs compared with other wildlife.

Storelli et al. [146] measured PCBs including coplanar PCBs in loggerhead sea turtles $(C$. caretta) from the eastern Mediterranean Sea. Concentrations of PCBs in loggerhead turtles ranged from 4.65 to $52.3 \mathrm{ng} / \mathrm{g}$ ww, and the estimated toxic equivalents of non- and mono-ortho PCBs ranged from 1.54 to $5.86 \mathrm{pg} \mathrm{TEQ} / \mathrm{g}$ ww. Alava et al. [148] measured PCBs in the loggerhead sea turtle egg yolk from North Carolina, eastern Florida, and western Florida, USA. The concentrations of PCBs ranged from 1.54 to $3,500 \mathrm{ng} / \mathrm{g}$ lw. PCB concentrations were higher in North Carolina egg samples than those in other regions, and an increasing gradient along the southeast coast around the Florida peninsula to North Carolina was found, likely due to the foraging site selection of the nesting females.

Stewart et al. [152] measured PCBs in fat and blubber of leatherback turtles (Dermochelys coriacea), and established baselines in blood and eggs in nesting turtles. Concentrations of PCBs in fat, blubber, blood, and egg were 4.87-188, $1.52-106,0.162-6.54$, and $0.441-19.1 \mathrm{ng} / \mathrm{g} \mathrm{ww}$, respectively. PCBs were found to be significantly and positively correlated between blood and eggs, suggesting maternal transfer. Camacho et al. [153] determined PCBs in green sea turtles (Chelonia mydas) and hawksbills (Eretmochelys imbricata) from the Boa Vista island, Cape Verde, Portugal. Higher concentrations of PCBs were detected in green turtles ( $\left.\sum \mathrm{PCBs} 0.73 \mathrm{ng} / \mathrm{g} \mathrm{ww}\right)$ than in hawksbills $(0.19 \mathrm{ng} / \mathrm{g} \mathrm{ww})$.

Hermanussen et al. [154] investigated levels of PCDD/Fs in green sea turtles from Moreton Bay, Queensland, Australia and found higher concentrations and TEQs in turtles foraging in close proximity to river inputs. The highest levels (PCDD/Fs $580 \mathrm{pg} / \mathrm{g} \mathrm{lw}$ and TEQs $2.7-160 \mathrm{pg} / \mathrm{g} \mathrm{lw}$ ) were elevated compared to levels reported in other higher trophic level wildlife, including seals from Greenland, Mediterranean dolphins, and Baikal seals. The results indicate that certain populations of green sea turtles that forage in close proximity to land-based secondary sources may be among the higher risk groups in terms of sensitivity to and metabolism of PCDD/Fs. Given the endangered status of many populations, future studies are needed to investigate sensitivity to and metabolism of PCDD/Fs in sea turtles. 


\subsection{Seabirds and Bird Eggs}

\subsubsection{Polar Region}

Dioxins and DLCs were examined in seabirds from the Canadian Arctic (Prince Leopold Island, Lancaster Sound) [155]. Black-legged kittiwakes (Rissa tridactyla) collected in 1993 contained $119 \mathrm{pg} / \mathrm{g}$ lw of $\sum$ PCDDs, $651 \mathrm{pg} / \mathrm{g}$ lw of $\sum$ PCDFs, and $7,436 \mathrm{pg} / \mathrm{g}$ lw of non-ortho PCBs ( $\sum$ NO-PCBs) in the liver. Comparable concentrations were observed in thick-billed murre (Uria lomvia), i.e., $169 \mathrm{ng} / \mathrm{g} \mathrm{pg} \mathrm{lw}$ of $\sum$ PCDDs, $431 \mathrm{pg} / \mathrm{g}$ lw of $\sum \mathrm{PCDFs}$, and 5,066 pg/g lw of $\sum \mathrm{NO}-\mathrm{PCBs}$, and northern fulmar (Fulmarus glacialis) contained elevated concentrations, i.e., 2,456, 7,218, and $24,067 \mathrm{pg} / \mathrm{g} \mathrm{lw}$ of $\sum$ PCDDs, $\sum$ PCDFs, and $\sum$ NO-PCBs, respectively. The $\sum$ TEQ values were $1,117,719$, and $8,192 \mathrm{pg} / \mathrm{g}$ lw in kittiwake, murre, and fulmar, respectively. The predominant $\mathrm{PCDD} / \mathrm{F}$ congener in all species was $2,3,4,7,8$ PeCDF. Of the measured non-ortho PCBs, PCB-126 occurred in the highest concentrations and contributed the majority of non-ortho PCB-TEQ in all three species. Braune and Simon [155] also investigated concentration changes from 1975 to 1993 , and they found that the concentrations of most PCDD/Fs decreased in the fulmars and kittiwakes but increased in the murres. Various metabolic capacities for PCDD/Fs and different migratory habits may result in those trends among species. Braune et al. [156] examined the liver tissues of northern fulmars collected in 2003 from Prince Leopold Island. The mean $\sum$ PCDD, $\sum$ PCDF, and $\sum$ NO-PCB concentrations were 47.3,154, and $519 \mathrm{pg} / \mathrm{g}$ lw, respectively, which were generally 1-2 orders of magnitude lower than the concentrations from the same species that were collected in 1993 [155]. Consequently, the $\sum$ TEQs declined from 1975 to 2003 in northern fulmars.

In another temporal study in the Canadian Arctic (Seymour Island), ivory gull (Pagophila eburnea) eggs exhibited concentration declines from 1976 to 2004 [157]. $\sum$ PCDD concentrations decreased from 207 to $55 \mathrm{pg} / \mathrm{g} \mathrm{lw}$, and $\sum$ PCDF and $\sum$ NO-PCB concentrations decreased from 61 to $24 \mathrm{pg} / \mathrm{g} \mathrm{lw}$ and from 6,970 to $2,220 \mathrm{pg} / \mathrm{g} \mathrm{lw}$, respectively. The $\sum$ TEQ also decreased from 697 to $193 \mathrm{pg} / \mathrm{g}$ lw. The $\sum$ TEQ concentrations were greater than the no observed adverse effect level (NOAEL) (10 pg/g ww) on reproduction reported in herring gulls [158]. In the far northwestern region of Russia, peregrine falcon eggs collected from 1987 to 2001 on the Kola Peninsula contained $\sum$ TEQ levels of 86-640 pg/g ww [159]. In Sweden, the $\sum$ TEQ concentrations ranged from 180 to $230 \mathrm{pg} / \mathrm{g}$ lw (7.5-8.4 pg/g ww) for PCDD/Fs and from 960 to 2,000 pg/g lw (50-100 pg/g ww) for co-planar PCBs [160].

Penguin blood was tested for dioxins and DLCs in Antarctica [161]. The mean $\sum \mathrm{PCDD}$ and $\sum \mathrm{PCDF}$ concentrations ranged from 6.5 to 22 and from 2.5 to $50 \mathrm{pg} / \mathrm{g}$ ww, respectively. PCDD/Fs were generally higher in males than in females for Gentoo (Pygoscelis papua) and Chinstrap penguins (Pygoscelis antarctica), which was likely related to the partial detoxification that occurred in females during egg formation [161]. The mean $\sum$ NO-PCB concentrations ranged from 200 to $720 \mathrm{pg} / \mathrm{g}$ 
ww in three species, including Adélie (Pygoscelis adeliae), Chinstrap, and Gentoo penguins. PCB-126 occurred at the highest concentrations among the four measured non-ortho PCBs. The total TEQs were 21, 12, and $62 \mathrm{pg} / \mathrm{g}$ ww in Adélie, Chinstrap, and Gentoo penguins, respectively.

\subsubsection{North America}

Custer et al. [162] investigated PCDD/Fs and PCBs in eggs from the piscivorous belted kingfisher (Ceryle alcyon) from the upper Hudson River, New York, USA, and compared them with concentrations in omnivorous spotted sandpipers (Actitis macularia) and insectivorous tree swallows (Tachycineta bicolor). Total PCB concentrations in swallow eggs (with a geometric mean of $6.8 \mu \mathrm{g} / \mathrm{g} \mathrm{ww}$ ) were approximately half of those present in kingfishers $(11.7 \mu \mathrm{g} / \mathrm{g} w \mathrm{w})$ or sandpipers $(12.6 \mu \mathrm{g} / \mathrm{g} \mathrm{ww})$. However, the $\sum \mathrm{TEQ}_{\mathrm{PCB}}$ values were higher in swallows $(1,790 \mathrm{pg} /$ $\mathrm{g}$ ww) than in the other two species (776 and $881 \mathrm{pg} / \mathrm{g} \mathrm{ww}$ ). Sum PCDD/F concentrations and $\sum \mathrm{TEQ} \mathrm{PCDD} / \mathrm{F}_{\mathrm{F}}$ values were also higher in the swallows than the other species. The authors suggested that metabolic pathway differences in the respective food chains of these three species likely accounted for the differences in the observed TEQ concentrations.

A site-specific exposure assessment of belted kingfisher was conducted in the Tittabawassee River floodplain, Midland, Michigan (USA), where the soil and sediments exhibited some of the highest levels of dioxin contamination ever reported [163]. PCDD/F concentrations were greater in belted kingfisher eggs and nestlings nesting along the Tittabawassee River when compared with those from upstream sites. The geometric mean $\sum \mathrm{PCDD} / \mathrm{F}$ concentrations were 130 and $200 \mathrm{pg} / \mathrm{g}$ ww in eggs and nestlings, respectively.

Tissues from eight bald eagles (Haliaeetus leucocephalus) found dead in the Upper Peninsula of Michigan, USA, in 2000 were examined for contaminants [164]. Their liver PCDD/F concentrations ranged from 23 to 4,500 pg/g ww. The total TEQs ranged from 100 to $9,100 \mathrm{pg} / \mathrm{g} \mathrm{ww}$, of which NO-PCBs accounted for $68-88 \%$. Some of the TEQ values were greater than the $\mathrm{LD}_{50}$ threshold levels reported in white leghorn chickens $(115 \mathrm{pg} / \mathrm{g} \mathrm{ww})$ or in double-crested cormorant embryos $(550 \mathrm{pg} / \mathrm{g}$ ww) $[165,166]$. Eagles with elevated TCDD or total PCB concentrations tended to have high TCDD/TCDF or PCB-126/PCB-77 ratios, which may suggest an induction of cytochrome P450 enzymes and the subsequent metabolism of TCDF and PCB-77. The TEQ concentrations generally exceeded the toxicity thresholds suggested for other avian species. Bald eagles from British Columbia, Canada (1989-1994), exhibited a mean $\sum$ TEQ of $600 \mathrm{pg} / \mathrm{g}$ ww in the liver tissues [167]. Birds with higher 2,3,7,8-TCDD concentrations tended to have low concentrations of 2,3,7,8-TCDF, indicating a hepatic cytochrome P4501A-type induction by TCDD and the subsequent metabolism of TCDF.

Great blue heron (Ardea herodias) eggs were collected from 1983 to 1998 along the coast of British Columbia, Canada and were evaluated for temporal changes in PCDD/Fs and PCBs [168]. The $\sum$ TEQ-TCDD/F concentrations declined markedly 
in the early 1990s, e.g., from $136 \mathrm{pg} / \mathrm{g}$ ww (1983) to $19 \mathrm{pg} / \mathrm{g} \mathrm{ww}$ (1998) in colonies located at the University of British Columbia. The authors attributed these declines to pulp mill changes from molecular chlorine bleaching to alternative bleaching technologies and the restricted use of chlorophenolic wood preservatives and antisap stains. The strong positive correlation between prey fish and heron egg contaminant levels suggested that local dietary uptake was an important route of exposure for herons.

The biomagnification factors (BMFs) of PCDDs, PCDFs, and non-ortho PCBs were investigated in the fish to osprey (Pandion haliaetus) egg food chain in the Willamette River, Oregon [169]. The BMFs ranged from no biomagnification to 174 (OCDD). The $\sum$ TEQ concentrations in the eggs ranged from 6 to $78 \mathrm{pg} / \mathrm{g} \mathrm{ww}$ for PCBs, from 2 to $24 \mathrm{pg} / \mathrm{g}$ ww for PCDDs, and from 10 to $99 \mathrm{pg} / \mathrm{g}$ ww for PCDFs. The eggs of ospreys (1999-2005) nesting along the lower portion of the Columbia River, USA, exhibited a geometric mean $\sum$ TEQ (including PCDDs, PCDFs, and PCBs) of $43.8 \mathrm{pg} / \mathrm{g}$ ww, which was significantly lower than the concentrations (mean $62.5 \mathrm{pg} / \mathrm{g} \mathrm{ww}$ ) observed in eggs collected in 1997-1998 from the same region [170]. Similar trends have also been found for many other organochlorine pesticides in osprey eggs from the studied watershed. Double-crested cormorant (Phalacrocorax auritus) eggs collected from the Great Lakes of North America in 1989 exhibited similar $\sum \mathrm{PCDD} / \mathrm{F}$ levels across various colonies, i.e., 1,720$2,740 \mathrm{pg} / \mathrm{g} \mathrm{lw}$ [171]. Eggs collected in 1991 from Lake Ontario contained elevated concentrations, i.e., $4,190 \mathrm{pg} / \mathrm{g} \mathrm{lw}$.

Dioxin-like toxic potency was also evaluated in Forster's tern (Sterna forsteri) eggs from Green Bay, Lake Michigan, in North America [172]. The average $\sum$ TEQs were 214.5 and 23.4 pg/g ww from Green Bay and Lake Poygan, respectively. These data suggest that dioxin-like effects were responsible for the intrinsic reproductive problems noted in Forster's terns from Green Bay, Lake Michigan. Notably, the reported NOAEL value for reproduction in Forster's tern was $200 \mathrm{pg} / \mathrm{g}$ ww [173].

\subsubsection{Europe}

Jiménez et al. [174] investigated dioxins in osprey eggs collected in Spain from 1994 to 2000. The $\sum \mathrm{PCDD} / \mathrm{F}$ and $\sum \mathrm{NO}-\mathrm{PCB}$ concentrations ranged from 2.6 to $14 \mathrm{pg} / \mathrm{g}$ ww and from 170 to $1,390 \mathrm{pg} / \mathrm{g}$ ww, respectively. The total TEQs ranged from 16 to $140 \mathrm{pg} / \mathrm{g}$ ww. Fifty-seven percent of examined eggs contained total PCB concentrations greater than the $4 \mu \mathrm{g} / \mathrm{g} w \mathrm{ww}$, NOAEL for reduced hatchability, embryo mortality, and deformities in bald eagles [175]. Eggs from yellow-legged gulls (Larus michahellis) and Audouin's gulls (Larus audouinii) collected in 2010 from the Ebro Delta Natural Park (Spain) contained $\sum$ PCDD/Fs of 160 and 84 pg/g lw and $\sum$ NO-PCBs of 3,100 and 6,460 pg/g lw, respectively. The mean $\sum$ TEQ concentrations were 290 and $540 \mathrm{pg} / \mathrm{g} \mathrm{lw}$ in these two gull species, respectively [176]. 
PCDD/Fs and dl-PCBs in herring gull eggs from the North Sea and Baltic Sea were analyzed [177]. The PCDD/F concentrations were 99-366 pg/g lw, and the dl-PCB concentrations were 726-2,085 ng/g lw. A general decreasing trend of $\mathrm{PCDD} / \mathrm{F}$ and dl-PCB concentrations in eggs was seen between 1988 and 2003 in both locations but the relative contaminant abundance was different. In eggs from the Baltic Sea island Heuwiese, the PCDD/F concentrations were somewhat lower than those from the North Sea islands, but dl-PCBs showed higher levels in the Baltic Sea island [177]. PCB, DDTs, and several other compounds were analyzed annually in guillemot eggs from the Baltic as part of the Swedish Environmental Monitoring Program [178]. The PCB concentrations varied among species and sites; however, they had decreased temporally by approximately 5-10\% per year since the end of the 1970s [178]. For example, the mean $\sum$ PCB concentration in guillemot eggs was approximately $300 \mu \mathrm{g} / \mathrm{g}$ lw in 1969 and $8.7 \mu \mathrm{g} / \mathrm{g}$ lw in 2011 $(n=430)$. Dioxins have been retrospectively analyzed in guillemot eggs, and significant decreasing trends were observed for TCDD, TCDF, and PCDD/Fs (1970-2011), with a decreasing rate from 1.2 to $5.1 \%$ annually. However, no trend was observed between 1990 and 2011 for TCDFs. The TEQs were calculated by using the $\mathrm{WHO}_{98}$ TEF [1], and the geometric mean value was estimated to be approximately 2,500 pg TEQ/g lw in 1969 and 800 pg TEQ/g lw in 2011 [178].

White-tailed sea eagle (Haliaeetus albicilla) eggs collected along the Swedish coast of the Baltic Sea from 1992 to 2004 contained $\sum$ PCDD, $\sum$ PCDF, and $\sum$ NOPCB concentrations of $0.4-4.1,1.2-5.3$, and 180-970 ng/g lw, respectively [35], compared to ranges of $0.11-0.16,0.22-0.33$, and $57-83 \mathrm{ng} / \mathrm{g} \mathrm{lw}$, respectively, in the Greenland population. Non-ortho PCBs were the major contributors to the total TEQs. No evidence was found to link the reproductive impairment in eagles to the DLC concentrations in their eggs. Another study on white-tailed sea eagle eggs from Sweden reported time trends for DDTs and $\sum$ PCBs over four decades [44]. The estimated mean concentrations of $\sum$ PCBs decreased in sea eagle eggs from $955 \mu \mathrm{g} / \mathrm{g} \mathrm{lw}$ in 1965 to $275 \mu \mathrm{g} / \mathrm{g}$ lw in 2010. Eggs from Audouin's gull (L. audouinii) and yellow-legged gull (Larus cachinnans) that were collected from the western Mediterranean in 1992 were evaluated for DLCs [179]. The $\sum$ NO-PCB and $\sum \mathrm{PCDD} / \mathrm{F}$ concentrations were 4,100 and $140 \mathrm{pg} / \mathrm{g} \mathrm{dw}$ in Audouin's gull, respectively, and they were 300 and $79 \mathrm{pg} / \mathrm{g} \mathrm{dw}$ in yellow-legged gull. The $\sum$ TEQ concentrations were 2,955 and $126 \mathrm{pg} / \mathrm{g}$ dw in these two species, respectively. The TEQ value in Audouin's gull was much greater than the NOAEL (10 pg/ $\mathrm{g} \mathrm{ww}$ ) for reproduction in herring gulls [158], and was comparable to the $\mathrm{LD}_{50}$ (550 pg/g ww) in double-crested cormorant embryos [166].

\subsubsection{Asia}

Piscivorous birds of various species from Japan contained dl-PCBs of 61$12,000 \mathrm{ng} / \mathrm{g} \mathrm{lw}$ and $\sum \mathrm{PCDD} / \mathrm{Fs}$ of $30-16,000 \mathrm{pg} / \mathrm{g} \mathrm{lw}$ in the liver [180]. The dl-PCB concentrations among the species were generally in the order of omnivores $>$ piscivores $>$ predators $>$ granivores that were from the same 
locations. The $\sum$ TEQ concentrations in aquatic birds ranged from 520 to $28,000 \mathrm{pg} /$ g lw.

Black-tailed gulls (Larus crassirostris) were also used as a bioindicator of dioxin contamination in their breeding grounds in Hokkaido, Japan [181]: the mean concentrations of $\sum \mathrm{NO}-\mathrm{PCBs}$ and $\sum \mathrm{PCDD} / \mathrm{Fs}$ were 9,150 and $76 \mathrm{pg} / \mathrm{g} \mathrm{lw}$ in fat and 4,905 and $53 \mathrm{pg} / \mathrm{g} \mathrm{lw}$ in eggs. The mean $\sum$ TEQ values were 712 and $382 \mathrm{pg} / \mathrm{g}$ lw in fat and eggs, respectively. The TEQ values reported in these studies were generally greater than the NOAEL $(10 \mathrm{pg} / \mathrm{g} \mathrm{ww})$ on reproduction in herring gull but lower than the NOAEL (200 pg/g ww) on reproduction in Forster's tern [158, 173].

PCBs including di-, mono-, and non-ortho PCBs were studied in the livers of common cormorants (Phalacrocorax carbo) from Lake Biwa, Japan [182]. The calculated mean $\sum$ TEQ-PCB concentration was $36 \mathrm{ng} / \mathrm{g}$ lw and was dominated by PCB-118, followed by PCB-126. A significant increase in ethoxyresorufin- $O$ deethylase (EROD) and pentoxyresorufin- $O$-deethylase (PROD) activities was observed in the studied cormorants, suggesting that the contamination level was sufficient to alter biochemical responses.

Dioxin and DLC concentrations were determined in the eggs, nestlings, and adults of black-footed albatross (BfA; Diomedea nigripes) and short-tailed albatross (StA; Diomedea albatrus) collected from Torishima Island in Japan in 2002 [183]. The total TEQs ranged from 1,400 to 2,900 pg/g lw in the BfA eggs and from 220 to 2,900 in the StA eggs, nestlings, and adults. The concentrations of PCDDs, with the exception of 1,2,3,7,8-PeCDD and high-chlorinated PCDFs, in 3-monthold BfA nestlings were lower than the concentrations in 1-month-old nestlings, suggesting a developmental dilution for these compounds. The estimated biomagnification factors of the examined compounds were greater in adults than in nestlings, except for 2,3,7,8-TCDF, PCB-77, Hx-CDD/Fs, and Oc-CDD/Fs. The authors hypothesized that this trend might be explained by the preferential metabolism of 2,3,7,8-TCDF and PCB-77 and the lower uptake efficiency of high-chlorinated congeners through the gastrointestinal tract in adults.

The tissue distribution of $\mathrm{PCDD} / \mathrm{Fs}$ was investigated in piscivorous birds from a heavily contaminated lake (Ya-Er Lake) in China in 1997 [184]. The concentration order of $\mathrm{PCDD} / \mathrm{F}$ within piscivorous birds was liver $>$ egg $\sim$ heart $>$ muscle $\sim$ stomach $>$ brain. The highest $\sum \mathrm{PCDD} / \mathrm{F}$ and $\sum$ TEQ concentrations were 1,690 and $552 \mathrm{pg} / \mathrm{g} \mathrm{lw}$, respectively, in the liver. $\mathrm{PCDD} / \mathrm{Fs}$ were also examined in the eggs from eight avian species in Dongting Lake, China [185]. $\sum \mathrm{PCDD} / \mathrm{F}$ concentrations ranged from 21 to $4,120 \mathrm{pg} / \mathrm{g}$ lw, and the $\sum$ TEQ of PCDD/Fs ranged from 2.5 to $17.4 \mathrm{pg} / \mathrm{g}$ lw in these species. Although the PCDD/F patterns in the eggs may be influenced by feeding habits, elimination, and metabolism, PCDD concentrations were generally greater than PCDFs in the studied species.

DLCs were examined in the subcutaneous fat of waterbirds from the Nakdong River Estuary (NRE) in Korea [186]. The mean $\sum \mathrm{PCDD} / \mathrm{F}$ concentration was $396 \mathrm{pg} / \mathrm{g} \mathrm{lw}$ in black-tailed gull (L. crassirostris), a resident bird of the estuary. Resident birds generally contained higher concentrations than migratory species, e.g., $198 \mathrm{pg} / \mathrm{g} \mathrm{lw}$ in greenshank (Tringa nebularia), $90 \mathrm{pg} / \mathrm{g} \mathrm{lw}$ in common gull 
(Larus canus) and $47 \mathrm{pg} / \mathrm{g} \mathrm{lw}$ in common tern (Sterna hirundo). These data suggested that the intake of locally contaminated fish near the NRE contributed substantially to the overall burdens of piscivorous birds residing in the estuary. The $\sum$ TEQ values ranged from 34 to $227 \mathrm{pg} / \mathrm{g}$ lw in avian species.

\subsection{Marine Mammals}

As top marine predators, marine mammals accumulate high body burdens of POPs via feeding over a long life span and transfer large amounts to their offspring via placental and lactational transfer. Because they accumulate complex mixtures of POPs and are sensitive to their effects, marine mammals present a "real world" exposure scenario and an early warning signal about chemicals which present the greatest risk to consumers at the top of the food chain, including humans. Marine mammals include cetaceans (whales, porpoises, and dolphins), pinnipeds (phocid seals and otarids), sea otters, sirenians (manatees and dugongs), and polar bears [187]. Apart from the otters, all of these taxa have a thick layer of blubber and spend most of their time in the ocean.

Marine mammals in many parts of the world carry a plethora of POPs in their tissues including PCBs and dioxins, OC pesticides, and compounds of emerging concern such as BFRs, PFASs, PCNs, and others. While emerging contaminants have been increasing in marine mammals [188-190], PCBs remain the predominant POP in lipid tissues and pose the greatest health risks to many populations [24-26, $68,191]$. Over the past four decades, elevated concentrations of endocrinedisrupting POPs have been linked with a number of deleterious effects in marine mammals including hormonal abnormalities, skeletal deformities, reproductive failure, neoplasms, and tumors [44, 46-50, 65, 67, 68, 192, 193]. PCBs and $\mathrm{PCDD} / \mathrm{Fs}$ have long been suspected to play a role in the recurring epizootics and large-scale mortalities among marine mammals, including the US Atlantic coast harbor seals ( $P$. vitulina) $[54,55]$ and bottlenose dolphins (T. truncatus) [56]; seals in the Baltic and North Seas [57, 58]; Mediterranean striped dolphins (S. coeruleoalba) [59-61]; Baikal seals ( $P$. sibirica) [62]; and Caspian seals (P. caspica) [63], among others. Feeding studies conducted in the mid-1980s and 1990s demonstrated the sensitivity of harbor seals to PCB and PCDD/F exposure and helped establish a threshold level for PCB-related immune suppression and other adverse effects in adult marine mammals [43, 48, 64-66]. Recent studies using a biomarker approach indicate that the threshold for PCB-induced immuneand endocrine disrupting effects in nursing seal pups is at least an order of magnitude lower [25, 67-70].

In some cases, restrictions on the production and use of PCBs and other POPs have resulted in decreasing concentrations in marine mammals, but in many parts of the world, these declines have leveled off since the mid- to late 1980s and relatively high levels of these pollutants, especially the PCBs, persist in tissues. 


\subsubsection{Polar Regions}

A review of temporal trends for legacy POPs (PCBs, OC pesticides) in the Arctic included 316 time series in biota from marine, freshwater, and terrestrial ecosystems in Canada, Alaska, Greenland, Iceland, and Norway (including ringed seals and polar bears) [194]. Most time series show decreasing concentrations of POPs, with only a few time-series showing significantly increasing trends.

Riget et al. [195] evaluated the levels and temporal trends of PCDD/Fs and dl-PCBs in ringed seal blubber collected in 1986, 1994, 1999, and 2003 from central East Greenland. The annual median concentrations of PCDDs and PCDFs were 5.4-24.4 pg TEQ/g ww and 2.5-5.1 pg TEQ/g ww, respectively. A decreasing trend was observed for PCDD/Fs and dl-PCBs since 1986, and annual decreases were $5.2 \%$ and $5.3 \%$ for $\mathrm{pg} \mathrm{TEQ} / \mathrm{g}$ ww of $\mathrm{PCDD} / \mathrm{Fs}$ and $\mathrm{dl}-\mathrm{PCB}$, respectively. In comparison, the levels of PCDD/Fs in 1986 were the highest recorded [195].

Hoguet et al. [196] assessed POP trends in beluga whales (Delphinapterus leucas) to determine whether restrictions on legacy POPs have led to concentration declines. PCBs were predominant contaminants in two subpopulations (Cook Inlet, Alaska, and the eastern Chukchi Sea), with median $\Sigma_{80} \mathrm{PCBs}$ concentrations of $2,360 \mathrm{ng} / \mathrm{g} \mathrm{lw}$ in blubber. $\sum_{32} \mathrm{PCBs}$ did not change over time; however, tetra-, penta-, and hepta-PCBs decreased by $7.1,6.8$, and $8.5 \%$, respectively, in males, whereas tetra-, penta-, and octa-PCBs declined by 11,12 , and $12.9 \%$, respectively, in females.

Trends in POP concentrations were assessed in adipose tissues of polar bears (Ursus maritimus) from East Greenland between 1983 and 2010 [197]. ¿PCBs and PCB congeners (CB-153, -180, and -170/190) showed statistically significant average yearly declines of $4.4 \%$ among subadults. Mean $\sum$ PCB concentrations declined from $22,730 \mathrm{ng} / \mathrm{g} \mathrm{lw}$ in $1983-1986$ to $8,473 \mathrm{ng} / \mathrm{g}$ lw in 2006-2010, about 2.7-fold. However, the authors concluded that despite declines resulting from international regulations, relatively high levels of these pollutants persist in East Greenland polar bear tissues [197].

McKinney et al. [198, 199] analyzed time trends of POP concentrations in adipose tissues sampled from the western Hudson Bay (WHB) polar bears. Over the 17-year period from 1991 to 2007, concentrations of $\Sigma$ PCBs and $\Sigma$ chlordane (CHL), the two POPs at the highest concentrations in all years ( $>1 \mathrm{ppm})$, showed no distinct trends even when compared to previous data for this subpopulation dating back to 1968; additionally, the PCB metabolites, $\Sigma \mathrm{MeSO}_{2}-\mathrm{PCBs}$ did not significantly change.

POP concentrations vary within and among circumpolar polar bear subpopulations. McKinney et al. [200, 201] measured geographic variation in PCBs in the adipose tissues of polar bears collected in 2005-2008 from 11 subpopulations in Alaska (AL), Canada including subarctic western and southern Hudson Bay (WHB, SHB), East Greenland (EG), and Svalbard (SV). $\sum$ PCB levels were elevated relative to all other monitored POPs and increased from west to east (subpopulations means ranging from 1,797 to $10,537 \mathrm{ng} / \mathrm{g} \mathrm{lw}$ ). 
Recent studies have examined the potential influence of global climate changelinked ecological changes on POP concentrations in polar bears and other arctic marine mammals (reviewed in [202]). McKinney et al. [198] first reported on climate-related changes in diet patterns in WHB polar bears, which altered time trends of POPs. Depleted carbon stable isotope ratios $\left(\delta_{13} C\right)$ and shifts in fatty acid profiles, as dietary tracers, in years when the sea ice broke up earlier in the summer were proposed to be associated with higher dietary proportions of subarctic seal species (harbor seals P. vitulina and harp seals Pagophilus groenlandicus) and lower proportions of arctic seals (bearded seals Erignathus barbatus). When time trends were compared to those adjusted for the influence of dietary tracers, the diet change resulted in slower rates of decrease of PCBs and faster rates of increase of newer POPs. A long-term study of East Greenland polar bears showed a substantial diet shift over the past three decades, specifically, decreases in Arctic-type ringed seals and increases in subarctic-type harp and hooded seals (C. cristata) using a statistical approach known as quantitative fatty acid signature analysis [203]. Higher consumption of subarctic seals occurred in years of warmer temperatures and lower ice extent, as shown by associations between prey consumption and the annual North Atlantic Oscillation (NAO) Index. Climate changes may thus influence the abundance, distribution, and/or accessibility of seal prey, changing polar bear diets. Declines in PCBs were generally faster in East Greenland than in western Hudson Bay polar bears. In addition, adjusting for the proportion of ringed seal in the East Greenland polar bear diet indicated that these POP declines were not as strongly influenced by the diet as observed in western Hudson Bay.

In the Antarctic, Schiavone et al. [204] assessed DLCs in blubber, liver, and muscle of Antarctic fur seal pups. In all seal tissues, PCDF concentrations were greater than PCDDs with total PCDD/F TEQ concentrations of 150, 164, and $89 \mathrm{pg} /$ $\mathrm{g}$ ww in blubber, liver, and muscle, respectively. These concentrations were higher than those found in previous studies of pinnipeds from the Antarctic [205, 206] possibly due to local sources on Livingston Island which hosts three permanent scientific bases.

\subsubsection{North America}

Trends in PCBs and dioxins have been examined in marine mammals along the US Atlantic coast since the 1970s. Lake et al. [207] reported a decrease in mean $\sum$ PCB concentrations in blubber of harbor seals ( $P$. vitulina concolor) from $17,100 \mathrm{ng} / \mathrm{g} \mathrm{lw}$ in 1980 to $9,500 \mathrm{ng} / \mathrm{g}$ lw in 1990-1992, suggesting that PCB levels had declined significantly since the early 1970 s when mean blubber concentrations in seals were approaching $\sim 100,000 \mathrm{ng} / \mathrm{g}$ lw [208]. Shaw and co-workers [55] reported higher mean PCB concentrations in harbor seal blubber $(55,000 \mathrm{ng} / \mathrm{g}$ lw in adult males; $43,000 \mathrm{ng} / \mathrm{g}$ lw in pups) [55]. Although lower than the 1970s levels, no declines in PCB concentrations in seal tissues were observed during the period 1991-2001, suggesting that the declines in PCB levels had leveled off since in the late 1980s. A similar trend was reported for European seals [209], and may reflect fresh inputs 
and/or an equilibrium in environmental cycling. A recent study reported current concentrations of PCBs in liver and blubber in this population [25]. Whereas blubber is the tissue commonly analyzed, liver may be more representative of recent exposure [210]. Hepatic $\Sigma_{30}$ PCB concentrations in the seals (overall mean $77,000 \mathrm{ng} / \mathrm{g} \mathrm{lw}$ ) exceeded blubber concentrations (overall mean 48,000 ng/g lw). Extremely high liver concentrations (mean 131,000 ng/g lw) were found in male pups, whereas PCB blubber concentrations were higher in the female pups $(47,000 \mathrm{ng} / \mathrm{g} \mathrm{lw})$ than the males, suggesting possible gender differences in PCB metabolism and accumulation in young seals. Regional trends were suggestive of fresh PCB sources in industrialized, densely populated southern coast of New England versus the rural north. The data suggest that PCB concentrations in northwest Atlantic harbor seals are constant or may even been increasing in industrialized southern parts of the range, most likely due to ongoing inputs from land-based reservoirs and existing (permitted) sources [25].

Kucklick et al. [211] investigated PCBs and OC pesticides in 300 blubber biopsies from coastal and near shore/estuarine male bottlenose dolphins ( $T$. truncatus) sampled along the US Atlantic and Gulf of Mexico coasts and Bermuda, and found significant regional differences in concentrations. Mean $\sum \mathrm{PCB}$ concentrations in dolphin blubber ranged from 33,000 to $450,000 \mathrm{ng} / \mathrm{g}$ lw among the sampling sites with the highest concentrations found in Brunswick, GA, a site heavily contaminated with the commercial PCB mixture Aroclor 1268. PCB-153, a recalcitrant congener associated with non-Aroclor 1268 formulations, was significantly associated with regional human population density, indicating this contaminant came from a general urban PCB source. Johnson-Restrepo et al. [27] examined PCB contamination in a Florida coastal food web. $\Sigma$ PCB concentrations (lw basis) in biota were in the order: forage fish (silver perch, striped mullet) and Atlantic sting-rays $<$ predator fish (red drum, hardhead catfish, spotted sea trout, spiny dogfish) $<$ Atlantic sharpnose sharks $<$ bull sharks and bottlenose dolphins. PCB concentrations in sharks and dolphins were one to two orders of magnitude greater than those in the lower trophic level fishes. The biomagnification factors (BMFs) for $\Sigma$ PCBs, calculated as the ratio between lipid-normalized concentrations in predator and prey, ranged, on average, from 3 to 502, indicating a high potential for biomagnification in this food web. The highest BMFs of $\Sigma$ PCBs were measured from forage fish (silver perch) to bottlenose dolphins and bull sharks (Carcharhinus leucas). Bull sharks are apex predators that inhabit estuarine, near-shore, and offshore waters of both the Gulf and the Atlantic coasts of Florida. These sharks are the only shark species to penetrate far into freshwater habitats.

On the US Pacific coast, She et al. [212] measured PCBs and DLCs in harbor seals from the San Francisco, CA area between 1989 and 1998. Overall, PCDD/F concentrations were low in these seals, but concentrations of non-ortho PCBs were relatively high ( $693 \mathrm{pg} / \mathrm{g} \mathrm{lw} ; 68 \mathrm{pg} \mathrm{TEQ/g} \mathrm{lw).} \mathrm{The} \mathrm{mean} \Sigma \mathrm{PCB}$ concentration in seal blubber was $71,000 \mathrm{ng} / \mathrm{g} \mathrm{lw}$, which is comparable to levels reported for Atlantic coast harbor seals. Pacific killer whales (Orcinus orca) living in the waters along the northwest coast of the USA and Canada are among the most contaminated marine mammals in the world. Ross et al. [45] measured PCDD/Fs and PCBs in 
blubber biopsies from the northern resident, southern resident, and transient populations of killer whales from the region, and found significant differences in PCB contamination among the three populations. The transient whales had the highest levels (mean adult male: $251,000 \mathrm{ng} / \mathrm{g} \mathrm{lw}$ ) followed by the southern residents (mean AM: 146,000 ng/g lw), with lower levels in the northern residents (mean adult male: $37,000 \mathrm{ng} / \mathrm{g} \mathrm{lw}$ ). Within each population, higher levels were found in the adult males compared with the females. The authors suggest that the contamination difference among the populations may partly be a result of trophic level and dietary differences. Resident populations feed mainly on fish such as salmon, while offshore transient killer whales feed mainly on marine mammals, e.g., sea lions [45].

\subsubsection{South America}

Dorneles et al. [26] analyzed PCBs and dioxins in blubber of false killer whales (Pseudorca crassidens), Guiana dolphins (Sotalia guianensis), rough-toothed dolphins (Steno bredanensis), and in liver of franciscana dolphins (Pontoporia blainvillei) collected from southeast and southern Brazil. Dl-PCBs accounted for over $83 \%$ of the total TEQ for all cetaceans. Total DLC concentrations ranged from 36 to $3,006 \mathrm{ng} / \mathrm{g}$ lw for franciscana dolphins, and from 356 to $30,776 \mathrm{ng} / \mathrm{g}$ for other delphinids. Mean $\Sigma$ PCB concentrations ranged from 35,000 to 279,000 ng/g lw, indicating that these cetaceans are highly contaminated, on par with the high PCB levels in transient Pacific coast killer whales. The high concentrations found in the study raised concern not only about the conservation of Brazilian coastal cetaceans, but also regarding possible human health risks from consumption of fish from Brazilian estuaries.

\subsubsection{Europe}

In 1990, the UK started its Cetacean Strandings Investigation Programme to gain greater understanding of contaminant levels in its marine mammal population. In an update on contamination status between 1990 and 2008, Law et al. [191] report sum PCB concentrations in harbor porpoise blubber ranged from $48 \mathrm{ng} / \mathrm{g}$ lw to $160,000 \mathrm{ng} / \mathrm{g} \mathrm{lw}$. Long term trends show an early decline in PCB concentration that has plateaued since about 1998. Different regions of the UK show somewhat different patterns. PCB concentrations have been steady in the East, variable around Scotland, and steadily decreasing in the West.

Storelli et al. [213] measured PCBs including dl-PCBs in melon, blubber, liver, kidney, lung, heart, and muscle tissue of striped dolphins (S. coeruleoalba) from the Eastern Mediterranean Sea (Adriatic Sea). The PCB concentrations ranged from 7 to $69,822 \mathrm{ng} / \mathrm{g}$ ww in the organs. Blubber and melon had the highest concentrations (22,000 and 16,400 ng/g ww, respectively) followed by liver (3,600 ng/g ww), and the other organs (mean range 220-725 ng/g ww). Total Dl-PCB TEQ in blubber 
was $120,000 \mathrm{pg} / \mathrm{g} \mathrm{ww}, 19,900 \mathrm{pg} / \mathrm{g} \mathrm{ww}$, and $21,000 \mathrm{pg} / \mathrm{g}$ ww in adult males, adult females, and newborns, respectively. Both the blubber PCB concentrations and the Dl-PCB TEQs exceeded estimated toxic thresholds for adverse effects in harbor seals $[43,45]$ thereby indicating that this population is likely under stress.

Imaeda et al. [214] investigated PCDD/Fs, PCBs, and dl-PCBs in the blubber of Baikal seals collected in 1992 and 2005. Dl-PCBs were one of the dominant contaminants, with concentrations ranging from 480 to $3,600 \mathrm{ng} / \mathrm{g} \mathrm{ww}$. Concentrations of PCDDs and PCBs in males were significantly higher than in females. In males, age-dependent accumulation was observed for PCDDs and mono-ortho PCBs, but PCDFs and non-ortho-PCBs showed no such trends implying that the seals may preferentially metabolize these contaminants or that exposure has been decreasing in recent years. Concentrations of PCDFs and non-ortho PCBs were significantly lower in 2005 than 1992, but no decreasing temporal trend of PCDDs, mono-ortho PCBs, or most non-dioxin like PCBs was observed. In 2005, TEQ levels in $40 \%$ of the specimens exceeded the threshold level for adverse effects in harbor seals (209 pg/g ww) [214], which raises concern for the future of the population.

\subsubsection{Asia}

Moon et al. [215] measured PCDD/Fs and dl-PCBs in the blubber of finless porpoises (Neophocaena phocaenoides) collected from Korean coastal waters. Total TEQ concentrations for PCDD/Fs and dl-PCBs were 6.5-31 pg/g lw, which were lower than those of cetaceans and pinnipeds reported from other countries and below the suggested threshold values for adverse health effects in marine mammals. Moon et al. [216] also measured PCDD/Fs and dl-PCBs in liver and blubber of minke whales and long-beaked common dolphins. It showed that PCDF and dl-PCB concentrations in blubber were 3-10 times higher than those in liver, but PCDDs were higher in liver. Concentrations of PCDD/Fs and dl-PCBs in liver and blubber of dolphins were significantly higher than those in whales, due to differences in habitat and diet [216]

Yang et al. [217] determined PCDD/Fs and PCBs in the blubber, liver, kidney, stomach, small intestine, and brains of Yangtze finless porpoises (the sole freshwater subspecies of finless porpoise) from Dongting Lake, China collected from 1998 to 2004. The results showed PCDD/F concentrations ranged from 65 to $1,563 \mathrm{pg} / \mathrm{g}$ lw in the organs, and PCBs ranged from 60 to $1,890 \mathrm{ng} / \mathrm{g} \mathrm{lw}$.

In 1998, Noël et al. [218] collected blubber biopsy samples from killer whales (O. orca) inhabiting the coastal waters around Possession Island, Crozet Archipelago, southern Indian Ocean, for contaminant analyses. The results showed that PCDD concentrations ranged from 5 to $77.1 \mathrm{pg} / \mathrm{g} \mathrm{lw}$, PCDFs ranged from 7 to $36.1 \mathrm{pg} / \mathrm{g} \mathrm{lw}$, and PCBs ranged from 4.4 to $20,500 \mathrm{ng} / \mathrm{g}$ lw. Over $70 \%$ of killer whales had blubber PCB concentrations above the PCB threshold established for endocrine disruption and immunotoxicity in young harbor seals, suggesting that PCBs cannot be ruled out as a threat to this declining population [218]. 


\subsubsection{Maternal Transfer}

POP concentrations in adult female marine mammals are generally lower than those in adult males due to the transfer of contaminants from females to their offspring during gestation and lactation, except in highly contaminated areas where females maintain higher body burdens due to ongoing exposure [45, 59, 219, 220]. Concentrations of a large suite of POPs were recently examined in the blubber and serum of juvenile and adult Hawaiian monk seals (Neomonachus schauinslandi) from the main Hawaiian Island subpopulation [221]. Adult females have the lowest blubber levels of most POPs, whereas adult males have the highest levels [221]. In contrast, a recent study showed that the blubber PCB concentrations in Tasmanian longfinned pilot whales (Globicephala melas) decreased with age in males because of growth dilution effect or decreasing levels of PCBs in the environment [222]. POPs were investigated in matched liver samples from five mother-fetus pairs of gray seals (Halichoerus grypus) [223], in blubber samples from 20 female sea lions and their fetuses during late pregnancy [224], and in Alaskan harbor seals ( $P$. vitulina) [225]. Significant amounts of PCBs and other POPs were transferred from female harbor seals to their fetuses during pregnancy and distributed among the fetal organs [225]. The prenatal transfer of these toxic contaminants may pose health risks to the fetus during early development.

Lactational transfer of PCBs and other POPs was examined in gray seal motherpup pairs from Scotland [226, 227]. Generally, concentrations of all contaminants increased in the mother and pup tissues from early lactation to late lactation. Mobilization of contaminants from the maternal inner blubber layer to the bloodstream was more efficient for less lipophilic compounds (lower $\log K_{\text {ow }}$ ) than for more lipophilic compounds, leading to selective transfer of lower $\log K_{\text {ow }}$ congeners to the pups. Exposure of young marine mammals to toxic contaminants both in utero and during nursing can lead to very high burdens in their developing bodies. Because of their greater sensitivity to developmental toxicity, Mos et al. [68] proposed a much lower toxicity reference value for PCB contamination $(1.3 \mu \mathrm{g} / \mathrm{g}$ lw) for pups than had been previously estimated for immunotoxicity in adults $(17 \mu \mathrm{g} / \mathrm{g} \mathrm{lw}[43])$.

\section{Health Effects and Risk}

\subsection{Endocrine Disruption}

Dioxins and PCBs affect the health of wildlife and their progeny by interfering with their endocrine system, which is responsible for maintaining homeostasis, reproduction, development, and/or behavior [40, 228]. Thus, dioxins and PCBs are known as endocrine disruptors (EDs). The magnitude of adverse effects depends 
on the body burden, dosage, frequency, and duration of exposure at different life stages [229]

Thyroid hormones play an important role in growth and development (including somatic and brain development) and in the maintenance of normal physiological status in vertebrates. Dioxins and PCBs can interfere directly with hormone synthesis in the thyroid gland [230-232], and disrupt thyroid hormone receptors and accessory proteins that directly control gene expression through the thyroid hormone responsive element [232]. Additionally, these pollutants competitively bind to thyroid hormone transport proteins in blood, such as transthyretin (TTR), and to membrane-bound transporters of target cells or to intracellular cytosolic thyroid hormone binding proteins, which are thought to act as modulators of nuclearreceptor-mediated transcription [232].

Brar et al. [233] studied thyroid endocrine-related effects and their relationship to accumulated contaminants in two indigenous fish species sampled from San Francisco Bay. Total triiodothyronine (T3) and total thyroxine (T4) levels varied significantly by location, with differing T3/T4 ratios in fish from some locations indicating altered peripheral deiodinase activity. The changes in levels of thyroid endocrine hormone were significantly correlated with hepatic concentrations of certain environmental contaminants. Exposure to a large number of polychlorinated biphenyl (PCB) congeners, both dioxin-like and non-dioxin-like, showed significant inverse correlations with T4 levels in the fish, while in contrast, T3 and T3/T4 ratio were positively correlated with $\mathrm{PCB}$ exposures. The positive correlation between T3/T4 ratio and PCB exposure supports the hypothesis that PCBs may alter T4 deiodination.

Similar results were found among northern fulmar $(F$. glacialis) populations from the Canadian Arctic and northern Europe [234]. Hepatic concentrations of dioxins, furans, and DL-PCBs were amongst the highest ever reported in northern seabirds. Hepatic EROD activity and plasma T4 levels were positively correlated with liver organochlorine levels, particularly with the dioxin-like compounds. Additionally, strong negative correlations were found between the dioxin-like compounds and plasma T3 levels. This study provides additional evidence that PCBs, dioxins, and furans may be associated with thyroid disruption [234].

Janz and Bellward [235] examined the effects of in ovo TCDD exposure on plasma thyroid hormone concentrations (T3, T4) and body and skeletal growth during the perinatal period in the domestic chicken (Gallus gallus), domestic pigeon (Columba livia), and great blue heron (A. herodias). They found that although hepatic EROD activity was induced 13- to 43-fold above controls in chicken, there was no effect of TCDD exposure on hatchability, body growth, subcutaneous edema, or plasma thyroid hormone levels. For pigeons exposed to TCDD, EROD activity was induced 6- to 15-fold, hatchability was decreased, liver to body weight ratio was elevated, and body and skeletal growth were decreased $(p<0.01)$; but there was no effect of TCDD exposure on plasma thyroid hormone levels. For herons, hepatic EROD activity was induced two- to threefold above control birds, similar to EROD activities measured in heron hatchlings exposed to environmental levels of TCDD and related chemicals in the Strait of Georgia, 
British Columbia. But at this level of TCDD exposure, there was no observed effect on plasma thyroid hormone levels or body growth in herons [235].

Field evidence has suggested that plasma PCBs and thyroid hormones are correlated in polar bears, apex predators in the Arctic food web [236]. Amongst females, there were significant correlations between five thyroid hormone variables and plasma PCB levels, but among males, PCBs were related to only two thyroid hormone variables, suggesting that female polar bears may be more susceptible to PCB-related thyroid hormone alterations than are males. In female polar bears from Svalbard, Norway, higher PCB concentrations were positively correlated with increasing plasma progesterone levels, which may indicate possible a defeminizing effect via inhibition of enzymes that convert progesterone to estrogen [237]. In Greenland polar bears, higher PCB and OC levels were negatively correlated with bone mineral density, suggesting a similar anti-estrogenic effect of the compounds [238, 239].

\subsection{Developmental/Reproductive Effects}

Dioxins, PCBs, and many other DLCs are estrogenic and may adversely affect reproductive functions in diverse species of biota. An abundance of evidence from laboratory and field studies suggests that DLCs can cause infertility [240, 241], reduced hatch rates in fish and birds, and decreased offspring viability in addition to altered hormone levels and adult sexual behaviors [242]. One example is the estrogenic induction of vitellogenin (Vtg) in fish [243]. Vtg is a complex phospholipoglycoprotein synthesized by the liver in response to estrogen stimulation. Vtg is secreted by the liver and transported in the blood to the ovary, where it is sequestered and cleaved into the yolk proteins lipovitellin and phosvitin, which are stored in the yolk and serve as a food reserve for the developing embryo [244]. High Vtg levels in male fish are associated with liver enlargement, feminization, and kidney damage, and are generally accompanied by various degrees of reproductive interference at similar or lower ambient estrogen concentrations [245-248]

Field studies have been conducted to address ecotoxicological concerns regarding PCB exposure in snapping turtles $(C$. serpentina). Eisenreich et al. [140] examined sublethal and lethal responses of juvenile snapping turtles that were exposed maternally and/or through diet to PCBs over 14 months post-hatching. Maternal exposure did not affect embryonic development or hatching success. Dietary PCB exposure reduced the metabolic rates of juveniles in two of the three assays. Kelly et al. [141] reported the accumulation and maternal transfer of PCBs in snapping turtles from the upper Hudson River, NY, USA, by using eggs and blood samples. Significant positive correlations were found between the carapace length and blood PCB concentrations for both sexes in contaminated areas. The results suggest that maternal transfer of PCBs to snapping turtle eggs and high body burdens pose reproductive risks to turtles in the upper Hudson River area. 
White-tailed sea eagles had very low population numbers in the 1980s which was linked with high levels of organochlorines (PCBs and DDT) [44, 52, 53]. However, since the banning of DDT and PCBs in the 1970s, reproductive health and population numbers have increased and DDT and PCB concentrations have decreased at fairly similar rates. The mean productivity of sea eagles increased from 0.3 in 1965 to 1.0 in the mid-1990s. Apart from eggshell thinning caused by DDE, PCBs have been correlated with impaired sea eagle reproduction, implying increased embryo mortality in eggs with elevated PCB concentrations [249]. High levels of PCB and DLCs were associated with adverse effects on reproduction and development in other avian predators including Alaskan peregrine falcons, bald eagles from the Aleutian Islands, glaucous gulls from Bjørnøya (Norway), and great black-backed gulls from northern Norway [237, 250].

Organochlorines (primarily PCBs) were suspected to be the underlying cause of reproductive failure in Baltic otters in the 1970s when reproduction plummeted to approximately 2\% [52]. Following PCB and DDT bans in the Baltic region, the frequency of adult female otters with signs of reproduction slowly recovered to approximately $67 \%$ in 2010 [44, 52].

Similarly, PCBs and DDT were implicated in the widespread reproductive impairment and population declines among seals from northwestern Europe $[48,51,251,252]$ and the disease complex observed in Baltic seals $[47,253]$. Because of high hunting pressure, the populations of gray and ringed seals in the Baltic decreased dramatically from 1,900 to approximately 1,950 [254]. Even after their protection, a further decrease followed and a disease complex, including uterine obstructions and tumors (leiomyomas) leading to impaired reproduction, was described [251, 253]. The disease complex was found at high frequencies among gray seals in the 1970-1980s [255], and a high contaminant concentration in their prey was proposed to be the underlying cause. PCBs were indicated as the primary suspect in the reproductive failure [47, 251] and were associated with tumors found in the uteri of older females [256]. Approximately $70 \%$ of the females had uterine obstructions in the early 1970 s, but the frequency decreased after the end of the 1980s. The pregnancy rate in examined seals increased from close to zero in the late 1970 s to close to $100 \%$ today. The first signs of recovery were observed approximately 15 years after the ban of PCBs and DDT $[44,52,53]$.

An early feeding study conducted by Reijnders [48] reported that reproductive failure in harbor seals from the Wadden Sea was linked to consumption of PCB-contaminated fish. This study was the first to demonstrate a causal relationship between contaminant levels and a physiological response in marine mammals. Subsequent feeding studies conducted in the Netherlands showed that harbor seals that consumed contaminated fish from the Wadden Sea or the Baltic Sea exhibited increased infertility and immunosuppression compared with seals consuming less-contaminated Atlantic fish [48, 64, 65]. 


\subsection{Immunotoxicity}

Although dioxins and PCBs are well-studied immunotoxicants in animals [257, 258], little attention was paid to this aspect of their potential toxicity in wildlife until the 1980s when a series of disease outbreaks resulted in mass mortalities among marine mammals, suggesting that the animals were susceptible to disease via PCB-induced suppression of their immune systems [45, 61, 259, 260]. A weight of evidence suggests that PCBs exert immune, endocrine disrupting, and reproductive effects in marine mammals, and PCB toxicity has been strongly implicated in the epizootics that have decimated many populations since the $1980 \mathrm{~s}$ $[43,45,68,261]$.

Harbor seals in polluted regions of Europe have experienced several virusinduced mortalities, starting with the 1988 morbiilvirus outbreak that resulted in the deaths of 20,000 animals [58, 262]. Similar to European harbor seals, the northwest Atlantic harbor seal population has been susceptible to viral disease outbreaks, as evidenced by a recurrence of epizootics since the late 1970s. In 1979-1980 and again in 1991-1992, viral epizootics resulted in the deaths of approximately 1,000 harbor seals from Maine to New York [54, 263, 264]. Between 2004 and 2009, approximately 2,000 harbor seals died of unknown causes during "Unusual Mortality Events" (UMEs) along the New England coast [265]. The possible contributory role of PCBs and DLCs in these events cannot be ruled out, since the PCB burdens alone in these seals exceed the estimated threshold levels for POP-mediated reproductive and immune system effects in the species $[25,43,55]$.

PCB-induced immunotoxicity has been implicated in several dolphin mortalities, rendering the animals susceptible to bacterial, viral, and parasitic infections. In 1987-1988, more than 740 bottlenose dolphins (T. truncates) stranded along the northwest Atlantic coast from New Jersey to central Florida [266]. It is estimated that this population may not return to pre-1987 population levels for 100 years [266]. Other similar large-scale dolphin mortalities have been reported in the Gulf of Mexico and in the Mediterranean Sea [60, 267].

Captive feeding studies conducted in the 1990s showed that harbor seals exhibited depressed immune responses if they consumed contaminated fish from the Baltic Sea rather than cleaner fish from the Atlantic Ocean [65, 66, 268]. An impairment of natural killer cell activity, in vitro T-lymphocyte function, antigenspecific in vitro lymphocyte proliferative responses and in vivo delayed-type hypersensitivity and antibody responses to ovalbumin were observed in the seals fed contaminated Baltic fish [65]. Similar feeding studies were conducted in European otters and mink [240, 241, 269, 270]. A study of northern fur seals found that various immune function parameters were negatively correlated to increasing PCB levels, including decreased antibody production after vaccination [271]. In Svalbard polar bears, a significant decrease in antibodies was associated with increased PCB levels [272]. A similar negative correlation was found between IgG levels and increasing PCB levels in the cubs. In the Svalbard/Resolute study, polar bears with high PCB levels exhibited immunosuppression expressed as 
reduced IgG production and lowered lymphocyte responses after vaccination [273]. These studies have provided valuable information for establishing a doseresponse relation between $\mathrm{PCB}$ exposure and adverse health effects for aquatic and marine mammals [43].

Based on the data from field and captive feeding studies in marine mammals and mink, Kannan et al. [43] proposed thresholds for immune and reproductive effects of $\Sigma$ PCBs in marine mammals of $8.7 \mu \mathrm{g} / \mathrm{g}$ lw in the liver and $17 \mu \mathrm{g} / \mathrm{g}$ lw in the blubber. Recent studies have applied these thresholds to estimate potential toxicity of current body burdens of POPs in marine mammals [191, 274]. In UK harbor porpoises with blubber $\Sigma$ PCB concentrations above $17 \mu \mathrm{g} / \mathrm{g}$ lw, those that died of infectious disease had higher $\Sigma$ PCB concentrations than those that died of traumatic injury, whereas there was no relationship between PCB concentrations and cause of death for porpoises with PCBs below the threshold [191].

Results of recent biomarker studies of PCB-sensitive endpoints in young freeranging harbor seals such as decreased immune function, vitamin $\mathrm{A}$, and thyroid hormones suggest that PCB-related adverse effects occur at much lower exposure concentrations in pups than previously demonstrated [67, 68, 70, 192, 275, 276]. Using No Observed Adverse Effect Levels (NOAELs) and allometrically scaled toxicity reference values (TRVs) from rodent studies, Mos et al. [68] proposed new TRVs (consisting of 5\% tissue residue concentration and dose) of $1,300 \mathrm{ng} / \mathrm{g}$ lw $\Sigma_{154} \mathrm{PCB}$ in the blubber of nursing harbor seal pups. These new TRVs were applied in a recent study of harbor seals along the northwest Atlantic to determine potential PCB-related immunotoxicity and other sublethal effects in the pups [25]. Blubber $\Sigma_{30} \mathrm{PCB}$ concentrations in $87 \%$ of the pups exceeded the threshold of 1,300 ng/g lw by an order of magnitude, implying that the majority of these pups may be suffering from PCB-related adverse effects that could diminish their overall fitness and increase their susceptibility to infectious disease during a vulnerable stage of development.

Given the pattern of recurring epizootics among seals and other marine mammal species, current tissue concentrations of PCBs and DLCs may pose a significant immunotoxic threat to the future health of many populations.

\subsection{Population Effects}

It is difficult to associate a specific compound or class of compounds with a specific health effect in the wild because there are thousands of contaminants in circulation, and many other biotic and abiotic factors may influence animal health. Because of the difficulty in making quantitative observations in the field, it is not easy to identify the types of disturbances that cause wildlife populations to be potentially at risk or reproductively compromised. Any causative mechanisms for altered reproductive parameters or population declines in aquatic biota are likely to be multifactorial and may involve a complex interplay of factors such as contaminant stress, habitat loss, accidents, noise, and climate change [74, 277, 278]. However, 
risk assessment can still be reasonably performed using a combination of approaches, including feeding studies, biomarker studies, weight of evidence, and extrapolation across species (e.g., from mink to marine mammals).

Chronic exposure to PCBs and DLCs impacts the fitness and sustainability of many wildlife populations today, especially apex predators such as sea turtles, sharks, and marine mammals [27, 45, 279, 280]. Overall, marine mammal health has been deteriorating over several decades, and trends in marine mammal disease reports are rising [174, 281]. In some regions such as the Baltic where levels of PCBs and OCs have been banned, the reproductive health of seals has gradually improved, and seal population numbers have increased [282]. A similar pattern has been observed for otters and white-tailed sea eagles [44].

The impact of dioxin and dl-PCB contamination on the reproductive health of populations of fish-eating birds including gray herons (Ardea cinerea), great cormorants ( $P$. carbo), osprey (Pandion halieaetus), and kingfishers (Alcedo atthis) in the Tokyo Bay area, Japan, has been a concern, although environmental levels have been decreasing [283]. A regional assessment of the ecological risks of dl-PCB exposure was performed to assess the need for risk management measures to protect these populations [283]. Egg mortality risk related to the contamination levels of dl-PCBs in eggs was determined to be relatively low (from $<1$ to $12 \%$ ), as were the changes in the population growth rates (lambda) $(<1$ to $2 \%)$, indicating that the current levels of dl-PCB contamination alone are not sufficient to trigger population-level effects.

However, some regions are still highly polluted and populations of high trophic level wildlife continue to suffer from disease and mass mortalities, in some cases, reducing population numbers to levels that cannot be sustained. It is estimated that more than one-third of marine mammals in the North Atlantic and Pacific are in danger of going extinct, according to the International Union for Conservation of Nature (IUCN) [280]. After accidental mortality, pollution is ranked as the prevalent cause of disease and death, affecting up to $60 \%$ of all marine mammals. Although it is arguable whether dioxins and PCBs are the primary cause of the mass mortalities affecting marine mammals and other top predators, these compounds have the potential to exacerbate the magnitude of disease outbreaks by compromising normal immune resilience in the animals [45, 284]. For many contaminant-stressed populations, the added stress of climate change is exacerbating the problem, causing shifts in food webs and threatening the survival of species, not only in the Arctic but in temperate oceans as well [280].

Vulnerable species such as polar bears living at the edge of their physiological tolerance range are at extreme risk. Of 19 subpopulations comprising some 25,000 polar bears, at least three are declining rapidly [285]. Canada's Western Hudson Bay (WHB) population has experienced a $22 \%$ decline or greater since the early 1980s; the Southern Beaufort Sea population plunged by about $40 \%$ over a 10 -year period from 2001 to 2010, dropping from about 1,500 bears to 900 bears before stabilizing; and the Baffin Bay population, shared by Greenland and Canada, is in steep decline [286]. The main factor driving these declines is the melting of Arctic sea ice, averaging $10 \%$ per decade, displacing the habitats and prey of polar bears, 
beluga whales, and walruses. But ironically, climate change alterations in food webs, lipid dynamics, ice and snow melt, organic carbon cycling, and severe storm events are expected to increase both the distribution and toxicity of POPs in coastal and oceanic environments [277]. Many scientists fear that this will trigger even larger-scale catastrophic events among marine mammals. The complex interplay of contaminant stress, climate change, and shifts in food web dynamics on vulnerable populations is an area urgently needing further research.

All seven species of marine turtles have been classified as threatened or endangered, and populations have declined steeply (by almost 95\%) in recent years [287]. The causes are unknown, but sea turtles face multiple threats from diverse hazards such as trawler nets, egg poaching, and pollution. Turtles are known to be robust to physical damage, but are surprisingly very susceptible to chemical contaminants [147]. An additional stress on populations is the expansion of fibropapillomas (FP), a benign neoplastic disease associated with a turtle herpesvirus that has increased significantly over the past 20 years [288]. FP is a global disease affecting turtles worldwide including the green sea turtle ( $C$. mydas), the loggerhead ( $C$. caretta), olive ridley (Lepidochelys olivacea), kemp's ridley (Lepidochelys kempii), and leatherbacks (D. coriacea) [288]. The disease tends to develop after the open-water pelagic developmental phase of approximately 10 years when juvenile turtles arrive and forage on seagrass and algae in nearshore environments with relatively small home ranges. Studies have linked a high prevalence of tumors in turtles to environmentally disturbed habitats, e.g., heavily polluted coasts with high human population density, proximity to river inputs, agricultural runoff, and land-based sources [289]. Immunosuppression is also strongly correlated with FP, but may be a consequence of the development and growth of FP, similar to other virus-induced tumors in other species [288]. The possible role of immunotoxic contaminants such as PCBs and dioxins in sea turtle disease and population declines is not understood and warrants further study.

\section{Conclusions}

\subsection{Data Gaps}

From four decades of field and semi-field (feeding) studies, we have a better understanding of the sources, exposure pathways, environmental levels, trends, and health effects of dioxins, PCBs, and related DLCs in aquatic ecosystems. However, data are lacking for many regions, contaminant patterns are changing over time, and large research gaps remain.

- Data are lacking for biota in many highly populated developing countries where the problems of inadequate waste management infrastructure and high volume of waste production are growing larger. Limitations in technical and financial support in these countries may exacerbate the problem. For aquatic biota from 
war-torn regions of the Middle East and Africa, contaminant data are non-existent.

- Many developing countries are still establishing contaminant inventories, which are essential before any technologies and measures can be put in place for source reduction. Bridging the data gap between developed and developing countries would provide a clear picture of the needs and options for effectively reducing global contamination.

- The rise of new and emerging persistent pollutants, poses a more complex global threat to both wildlife and humans. While it is known that dioxins and PCBs are linked to cancers, reproductive impairment, and immune system dysfunction in animals, more studies are warranted to understand the extent of the compounded health threat posed by the introduction of emerging POPs.

- Extrapolating from recent trend studies, PCBs remain the predominant contaminants in fish, seabirds, turtles, sharks, and marine mammals, but in certain food webs, bioaccumulation and magnification of PCDD/Fs and dl-PCBs are evident, presenting an increased health risk to marine animals. The synergistic interactions and effects due to exposure to contaminant mixtures in aquatic biota need further investigation.

- Technology has been advancing at an exponential rate, and it is important to use advances in analytical chemistry to advance our science. The evolution of electronic tracking tags might provide an alternative for tracking long-distance migrating species [290].

- Data quality is crucial to decision-making leading to resource management and contaminant regulation. Standardization of sampling, storage, and analytical protocols and harmonization of analytic methods could improve the integrity of collected data across the studies. Additionally, an international, public database for reporting POP levels and mass mortalities in wildlife might facilitate scientific discovery and allow for timely response to warning signals from contaminant-stressed populations.

- Biological effects of dioxins and PCBs are generally first observed in populations with high-level exposure, often accompanied by catastrophic events such as reproductive failure or disease outbreaks. More biomarker studies are needed to advance understanding of the range of health effects associated with moderate to low-level exposure, especially in species and populations in decline, e.g., sea turtles. The possible role of immunotoxic PCBs and dioxins in sea turtle tumors (FPs) and declining numbers worldwide is not understood and warrants further study.

- Climate change alterations in food webs, lipid dynamics, ice and snow melt, organic carbon cycling, and severe storm events are expected to increase both the distribution and toxicity of POPs in coastal and oceanic environments [277]. Many scientists fear that this will trigger widespread, large-scale catastrophic events among marine mammals and other high trophic level wildlife. The complex interplay of contaminant stress, climate change, and shifts in food web dynamics on vulnerable populations such as polar bears is an area urgently needing further research. 


\subsection{Foresight from Current Knowledge}

Dioxins, PCBs, and DLCs are major industrial chemicals that are globally restricted, but still pose a significant health threat to diverse species of aquatic biota, particularly those at high trophic levels. Although PCBs were banned in most developed countries four decades ago, landstocked sources such as old PCB-containing equipment and landfills will remain a reservoir for PCB releases for years to come. Tanabe [291] predicted that most of the PCBs $(66 \%)$ were stockpiled in products (transformers and capacitors) long after PCBs were banned from production in the 1970s. Trend studies suggest that the amounts of PCBs cycling in aquatic and marine food webs are gradually decreasing, as burial, metabolism, and degradation occur in sediments. However, certain uses of PCBs are still permitted in the USA and Europe, delivering fresh inputs to aquatic food webs. As a result, the large declines observed in PCBs after the bans have plateaued in most developed countries, and in some regions, environmental levels are remaining constant or even increasing. Similarly, regulatory actions aimed at controlling PCDD/Fs and PBDD/Fs have been inefficient, as these compounds continue to be released as by-products of combustion and other industrial and agricultural processes.

With the ongoing challenges associated with POP contamination, continuous efforts are needed to monitor the occurrence, distribution, and health effects in biota with emphasis on highly exposed species with body burdens close to or higher than estimated threshold levels of effect. Thresholds with high uncertainties should be interpreted as warning signals that require more data and further study.

Overall, the future trends for dioxins, PCBs, and related DLCs in aquatic biota are unclear. Given the large reservoir of these compounds in the environment, and ongoing releases and inputs from permitted sources, regulatory controls will do little to impede the continued cycling of these chemicals through aquatic and marine ecosystems for the foreseeable future.

\section{References}

1. Van den Berg M, Birnbaum LS, Bosveld ATC, Brunstrom B, Cook P, Feeley M, Giesy JP, Hanberg A, Hasegawa R, Kennedy SW, Kubiak T, Larson JC, van Leeuwen FXR, Liem AKD, Nolt C, Peterson RE, Poellinger L, Safe S, Schrenk D, Tillitt DE, Tysklind M, Younes M, Waern F, Zacharewski T (1998) Toxic equivalency factors (TEFs) for PCBs, PCDDs, PCDFs for humans and wildlife. Environ Health Perspect 106(12):775-792

2. Van den Berg M, Birnbaum LS, Denison MS, De Vito M, Farland W, Feeley M, Fiedler H, Hakansson H, Hanberg A, Haws LC, Rose M, Safe S, Schrenk D, Tohyama C, Tritscher A, Tuomisto J, Tysklind M, Walker N, Petersonq RE (2006) The 2005 World Health Organization reevaluation of human and mammalian toxic equivalency factors for dioxins and dioxin-like compounds. Toxicol Sci 93(2):2223-2241

3. Van den Berg M, Denison MS, Birnbaum LS, DeVito MJ, Fiedler H, Falandysz J, Rose M, Schrenk D, Safe S, Tohyama C, Tritscher A, Tysklind M, Peterson RE (2013) 
Polybrominated dibenzo-p-dioxins, dibenzofurans, and biphenyls: inclusion in the toxicity equivalency factor concept for dioxin-like compounds. Toxicol Sci 133(2):197-208

4. Ba T, Zheng M, Zhang B, Liu W, Xiao K, Zhang L (2009) Estimation and characterization of $\mathrm{PCDD} / \mathrm{Fs}$ and dioxin-like PCBs from secondary copper and aluminum metallurgies in China. Chemosphere 75:1173-1178

5. Hutzinger O, Blumich MJ (1985) Sources and fate of PCDDs and PCDFs: an overview. Chemosphere 14:581-600

6. Liu G, Zheng M, Liu W, Wang C, Zhang B, Gao L, Su G, Xiao K, Lv P (2009) Atmospheric emission of PCDD/Fs, PCBs, hexachlorobenzene, and pentachlorobenzene from the coking industry. Environ Sci Technol 43:9196-9201

7. Olie K, Vermeulen PL, Hutzinger O (1977) Chlorodibenzo-p-dioxins and chlorodibenzofurans are trace components of fly ash and flue gas of some municipal incinerators in the Netherlands. Chemosphere 6:455-459

8. Fiedler H, Hutzinger O, Timms CW (1990) Dioxins: sources of environmental load and human exposure. Toxicol Environ Chem 29:157-234

9. US EPA (2003) Sources of dioxin-like compounds in the United States. In: U.S. EPA (ed) Exposure and human health reassessment of 2,3,7,8-tetrachlorodibenzo-p-Dioxin (TCDD) and related compounds national academy sciences (NAS). U.S. Environmental Protection Agency, Washington, DC

10. US EPA (2013) Update to an inventory of sources and environmental releases of dioxin-like compounds in the United States for the Years 1987, 1995, and 2000 U.S. Environmental Protection Agency, Washington, DC: EPA/600/R-11/005A

11. Chang MB, Lin JJ (2001) Memory effect on the dioxin emissions from municipal waste incineration in Taiwan. Chemosphere 45:1151-1157

12. Hylander LD, Sollenberg H, Westas H (2003) A three-stage system to remove mercury and dioxins in flue gases. Sci Total Environ 304:137-144

13. Hagenmaier H, She J, Lindig C (1992) Persistence of polychlorinated dibenzo-p-dioxins and polychlorinated dibenzofurans in contaminated soil at Maulach and Rastatt in southwest Germay. Chemosphere 25:1449-1456

14. She J, Hagenmaier H (1994) PCDDs and PCDFs with chloralkali pattern in soil and sludge samples. Organohalogen Compd 20:261-264

15. Weber R, Kuch B (2003) Relevance of BFRs and thermal conditions on the formation pathways of brominated and brominated-chlorinated dibenzodioxins and dibenzofurans. Environ Int 29:699-710

16. Hanari N, Kannan K, Miyake Y, Okazawa T, Kodavanti PRS, Aldous KM, Yamashita N (2006) Occurrence of polybrominated biphenyls, polybrominated dibenzo-p-dioxins, and polybrominated dibenzofurans as impurities in commercial polybrominated diphenyl ether mixtures. Environ Sci Technol 40:4400-4405

17. Ren M, Peng P, Cai Y, Chen D, Zhou L, Chen P, Hu J (2011) PBDD/F impurities in some commercial deca-BDE. Environ Pollut 159:1375-1380

18. Birnbaum LS, Staskal DF, Diliberto JJ (2003) Health effects of polybrominated dibenzo-pdioxins (PBDDs) and dibenzofurans (PBDFs). Environ Int 29:855-860

19. Kannan K, Liao C-Y, Moon H-B (2012) Polybrominated dibenzo-p-dioxins and dibenzofurans. In: Schecter A (ed) Dioxins and health. Wiley, New York, pp 255-302

20. Shaw SD, Blum A, Weber R, Kannan K, Rich D, Lucas D, Koshland CP, Dobraca D, Hanson S, Birnbaum LS (2010) Halogenated flame retardants: do the fire safety benefits justify the risks? Rev Environ Health 25(4):261-305

21. Tanabe S (1988) PCB problems in the future: foresight from current knowledge. Environ Pollut 50:5-28

22. Binelli A, Provini A (2003) The PCB pollution of Lake Iseo (N. Italy) and the role of biomagnification in the pelagic food web. Chemosphere 53:143-151 
23. Naso B, Perrone D, Ferrante MC, Bilancione M, Lucisano A (2005) Persistent organic pollutants in edible marine species from the Gulf of Naples, Southern Italy. Sci Total Environ 343:83-95

24. Letcher RJ, Gebbink WA, Sonne C, Born EW, McKinney MA, Dietz R (2009) Bioaccumulation and biotransformation of brominated and chlorinated contaminants and their metabolites in ringed seals (Pusa hispida) and polar bears (Ursus maritimus) from East Greenland. Environ Int 35:1118-1124

25. Shaw SD, Berger ML, Weijs L, Paepke O, Covaci A (2014) Polychlorinated biphenyls still pose significant health risks to northwest Atlantic harbor seals. Sci Total Environ 490:477-487

26. Dorneles PR, Sanz P, Eppe G, Azevedo AF, Bertozzi CP, Martinez MA, Secchi ER, Barbosa LA, Cremer M, Alonso MB, Torres JPM, Lailson-Brito J, Malm O, Eljarrat E, Barcelo D, Das K (2013) High accumulation of PCDD, PCDF, and PCB congeners in marine mammals from Brazil: a serious PCB problem. Sci Total Environ 463-464:309-318

27. Johnson-Restrepo B, Kannan K, Addink R, Adams DH (2005) Polybrominated diphenyl ethers and polychlorinated biphenyls in a marine foodweb of coastal Florida. Environ Sci Technol 39:8243-8250

28. Senthil Kumar K, Kannan K, Paramasivan ON, Sundaram VPS, Nakanishi J, Masunaga S (2001) Polychlorinated dibenzo-p-dioxins, dibenzofurans, and polychlorinated biphenyls in human tissues, meat, fish, and wildlife samples from India. Environ Sci Technol 35:3448-3455

29. Park J-S, Kalantzi OI, Kopec D, Petreas M (2009) Polychlorinated biphenyls (PCBs) and their hydroxylated metabolites (OH-PCBs) in livers of harbor seals (Phoca vitulina) from San Francisco Bay, California and Gulf of Maine. Mar Environ Res 67:129-135

30. Weijs L, Dirtu AC, Das K, Gheorghe A, Reijnders PJH, Neels H, Blust R, Covaci A (2009) Inter-species differences for polychlorinated biphenyls and polybrominated diphenyl ethers in marine top predators from the Southern North Sea: Part 1. Accumulation patterns in harbour seals and harbour porpoises. Environ Pollut 157:437-444

31. Wang D, Shelver WL, Atkinson S, Mellish J, Li QX (2010) Tissue distribution of polychlorinated biphenyls and organochlorine pesticides and potential toxicity to Alaskan northern fur seals assessed using PCBs congener specific mode of action schemes. Arch Environ Contam Toxicol 58:478-488

32. Wolkers H, Hammill MO, van Bavel B (2006) Tissue-specific accumulation and lactational transfer of polychlorinated biphenyls, chlorinated pesticides, and brominated flame retardants in hooded seals (Cistophora cristata) from the Gulf of St. Lawrence: applications for monitoring. Environ Pollut 142:476-486

33. Kubo K, Yamaguchi K, Mitsuhashi M, Hattori K, Tanaka S (2013) Concentration profiles of PCB congeners in the blubber and liver of Steller sea lions (Eumetopias jubatus) from the coast of Hokkaido, Japan. Mar Pollut Bull 69:228-232

34. Strid A, Jörundsdóttir H, Päpke O, Svavarsson J, Bergman A (2007) Dioxins and PCBs in Greenland shark (Somniosus microcephalus) from the north-east Atlantic. Mar Pollut Bull 54:1514-1522

35. Nordlöf U, Helander B, Zebühr Y, Bignert A, Asplund L (2012) Polychlorinated dibenzo-pdioxins, polychlorinated dibenzofurans and non-ortho-PCBs in eggs of white-tailed sea eagles collected along the Swedish coast in the Baltic Sea. Sci Total Environ 438:166-173

36. Bianco G, Zianni R, Anzillotta G, Palma A, Vitacco V, Scrano L (2013) Dibenzo-p-dioxins and dibenzofurans in human breast milk collected in the area of Taranto (Southern Italy): first case study. Anal Bioanal Chem 405:2405-2410

37. Srogi K (2008) Levels and congener distributions of PCDDs, PCDFs and dioxin-like PCBs in environmental and human samples: a review. Environ Chem Lett 6:1-28

38. Wittsiepe J, Fobil JN, Till H, Burchard G-D, Wilhelm M, Feldt T (2015) Levels of polychlorinated dibenzo-p-dioxins, dibenzofurans $(\mathrm{PCDD} / \mathrm{Fs})$ and biphenyls $(\mathrm{PCBs})$ in 
blood of informal e-waste recycling workers from Agbogbloshie, Ghana, and controls. Environ Int 79:65-73

39. Annamalai J, Namasivayam V (2015) Endocrine disrupting chemicals in the atmosphere: their effects on humans and wildlife. Environ Int 76:78-97

40. Colborn T, Vom Saal FS, Soto AM (1993) Developmental effects of endocrine-disrupting chemicals in wildlife and humans. Environ Health Perspect 101:378-384

41. De Guise S, Shaw SD, Barclay J, Brock J, Brouwer A, Dewailly E, Fair PA, Fournier M, Grandjean P, Guillette L, Hahn M, Koopman-Esseboom C, Letcher R, Matz A, Norstrom R, Perkins C, Schwacke LH, Skaare JU, Sowles J, St. Aubin DJ, Stegeman J, Whaley J (2001) Consensus Statement: Atlantic coast contaminants workshop 2000. Environ Health Perspect 109(12):1301-1302

42. Fisk AT, Hobson KA, Norstrom RJ (2001) Influence of chemical and biological factors on trophic transfer of persistent organic pollutants in the northwater polynya marine food web. Environ Sci Technol 35:732-738

43. Kannan K, Blankenship AL, Jones PD, Giesy JP (2000) Toxicity reference values for the toxic effects of polychlorinated biphenyls to aquatic mammals. Hum Ecol Risk Assess 6 (1):181-201

44. Roos AM, Bäcklin B-MVM, Helander BO, Rigét FF, Eriksson UC (2012) Improved reproductive success in otters (Lutra lutra), grey seals (Halichoerus grypus) and sea eagles (Haliaeetus albicilla) from Sweden in relation to concentrations of organochlorine contaminants. Environ Pollut 170:268-275

45. Ross PS, Ellis GM, Ikonomou MG, Barrett-Lennard LG, Addison RF (2000) High PCB concentrations in free-ranging Pacific killer whales, Orcinus orca: effects of age, sex and dietary preference. Mar Pollut Bull 40(6):504-515

46. De Wit C, Fisk AT, Hobbs KE, Muir DCG, Gabrielsen GW, Kallenborg R, Krahn MM, Norstrom RJ, Skaare JU (2004) AMAP assessment 2002: persistent organic pollutants in the Arctic. Arctic Monitoring and Assessment Programme, Oslo

47. Helle E, Olsson M, Jensen S (1976) DDT and PCB levels and reproduction in ringed seal from the Bothnian Bay. Ambio 5:188-189

48. Reijnders PJ (1986) Reproductive failure in common seals feeding on fish from polluted coastal waters. Nature 324:456-457

49. Routti H, Nyman M, Jenssen BM, Backman C, Koistinen J, Gabrielsen GW (2008) Bonerelated effects of contaminants in seals may be associated with vitamin D and thyroid hormones. Environ Toxicol Chem 27(4):873-880

50. Ylitalo GM, Stein JE, Hom T, Johnson LL, Tilbury KL, Hall AJ, Rowles T, Greig DJ, Lowenstine LJ, Gulland FMD (2005) The role of organochlorines in cancer-associated mortality in California sea lions (Zalophus californianus). Mar Pollut Bull 50:30-39

51. Olsson M, Sandegren F (1991) Is PCB partly responsible for the decline of the otter in Europe? In: Reuter C, Röchert R (eds) Proceedings of the V international Otter Colloquium, Habitat, Hankensbúttel, vol 6, pp 223-227

52. Roos A, Greyerz E, Olsson M, Sandegren F (2001) The otter (Lutra lutra) in Sweden population trends in relation to sumDDT and total PCB concentrations during 1968-99. Environ Pollut 111:457-469

53. Tison JL, Blennow V, Palkopoulou E, Gustafsson P, Roos A, Dalén L (2014) Population structure and recent temporal changes in genetic variation in Eurasian otters from Sweden. Conserv Genet 16:371-384

54. Geraci JR, St. Aubin DJ, Barker IK, Webster RG, Hinshaw VS, Bean WJ, Ruhnke L, Prescott JH, Early G, Baker AS, Madoff S, Schooley RT (1982) Mass mortality of harbor seals: pneumonia associated with Influenza A virus. Science 215(4536):1129-1131

55. Shaw SD, Brenner D, Bourakovsky A, Mahaffey CA, Perkins CR (2005) Polychlorinated biphenyls and chlorinated pesticides in harbor seals (Phoca vitulina concolor) from the northwestern Atlantic coast. Mar Pollut Bull 50:1069-1084 
56. Lipscomb TP, Schulman FY, Moffett D, Kennedy S (1994) Morbilliviral disease in Atlantic bottlenose dolphins (Tursiops truncatus) from the 1987-1988 epizootic. J Wildl Dis 30:567-571

57. Dietz R, Ansen CT, Have P, Heide-Jørgensen MP (1989) Clue to seal epizootic. Nature 338 (6217):627

58. Osterhaus ADME, Vedder EJ (1988) Identification of virus causing recent seal deaths. Nature $335: 20$

59. Aguilar A, Borrell A (1994) Reproductive transfer and variation of body load of organochlorine pollutants with age in fin whales (Balaenoptera physalus). Arch Environ Contam Toxicol 27:546-554

60. Aguilar A, Raga JA (1993) The striped dolphin epizootic in the Mediterranean Sea. Ambio 22 (8):524-528

61. Domingo M, Visa J, Pumarola M, Marco AJ, Ferrer L, Rabanal R, Kennedy S (1992) Pathologic and immunocytochemical studies of morbillivirus infection in striped dolphins (Stenella coeruleoalba). Vet Pathol 29:1-10

62. Likhoshway YV, Grachev MA, Kumarev VP (1989) Baikal seal virus. Nature 339:266

63. Kennedy S, Kulken T, Jepson PD, Deaville R, Forsyth M, Barrett T, van de Bildt MWG, Osterhaus ADME, Eybatov T, Duck C, Kydyrmanov A, Mitrofanov IV, Wilson S (2000) Mass die-off of Caspian seals caused by canine distemper virus. Emerging Infect Dis 6:637-639

64. Brouwer A, Reijnders PJH, Koeman JH (1989) Polychlorinated biphenyl (PCB)contaminated fish indices vitamin A and thyroid hormone deficiency in the common seal (Phoca vitulina). Aquat Toxicol 15:99-106

65. De Swart RL, Ross PS, Vedder LJ, Timmerman HH, Hoisterkamp S, Van Loveren H, Vos JG, Reijnders PJH, Osterhaus ADME (1994) Impairment of immune function in harbor seals (Phoca vitulina) feeding on fish from polluted waters. Ambio 23(2):155-159

66. Ross PS, De Swart RL, Reijnders PJH, Loveren HV, Vos JG, Osterhaus ADME (1995) Contaminant-related suppression of delayed-type hypersensitivity and antibody responses in harbor seals fed herring from the Baltic sea. Environ Health Perspect 103(2):162-167

67. Mos L, Morsey B, Jeffries SJ, Yunker MB, Raverty S (2006) Chemical and biological pollution contribute to the immunological profiles of free-ranging harbor seals. Environ Toxicol Chem 25(12):3110-3117

68. Mos L, Cameron M, Jeffries SJ, Koop BF, Ross PS (2010) Risk-based analysis of polychlorinated biphenyl toxicity in harbor seals. Integr Environ Assess Manage 6 (4):631-640

69. Ross PS, De Swart RL, Addison R, Van Loveren H, Vos JG, Osterhaus ADME (1996) Contaminant-induced immunotoxicity in harbour seals: wildlife at risk? Toxicology 112:157-169

70. Tabuchi M, Veldhoen N, Dangerfield N, Jeffries SJ, Helbing CC, Ross PS (2006) PCB-related alteration of thyroid hormones and thyroid hormone receptor gene expression in free-ranging harbor seals (Phoca vitulina). Environ Health Perspect 114:1024-1031

71. Bogen G (1979) Symptoms in Vietnam veterans exposed to Agent Orange. JAMA 242:2391-2391

72. Webster TF, Commoner B (2003) Overview: the dioxin debate. In: Schecter A, Gasiewicz TA (eds) Dioxins and health. Wiley, Hoboken, pp 1-53

73. Addink R, Olie K (1995) Mechanisms of formation and destruction of polychlorinated dibenzo-p-dioxins and dibenzofurans in heterogeneous systems. Environ Sci Technol 29:1425-1435

74. Evans RM (1988) The steroid and thyroid hormone receptor superfamily. Science 240:889-895

75. Hagenmaier H, Kraft M, Brunner H, Haag R (1987) Catalytic effects of fly ash from waste incineration facilities on the formation and decomposition of polychlorinated dibenzo-pdioxins and polychlorinated dibenzofurans. Environ Sci Technol 21:1080-1084 
76. Öberg LG, Rappe C (1992) Biochemical formation of PCDD/Fs from chlorophenols. Chemosphere 25:49-52

77. Weber R, Iino F, Imagawa T, Takeuch M, Sakurai T, Sadakata M (2001) Formation of PCDF, PCDD, PCB, and PCN in de novo synthesis from PAH: Mechanistic aspects and correlation to fluidized bed incinerators. Chemosphere 44:1429-1438

78. UNEP (1999) Dioxin and furan inventories: National and regional emissions of PCDD/ PCDF. United Nations Environment Programme Chemicals, Geneva

79. Baker JI, Hites RA (2000) Is combustion the major source of polychlorinated dibenzo-pdioxins and dibenzofurans to the environment? A mass balance investigation. Environ Sci Technol 34:2879-2886

80. Kannan K, Watanabe I, Giesy JP (1998) Congener profile of polychlorinated/brominated dibenzo-p-dioxins and dibenzofurans in soil and sediments collected at a former chlor-alkali plant. Toxicol Environ Chem 67:135-146

81. Kuehl DW, Butterworth BC, Devita WM, Sauer CP (1987) Environmental contamination by polychlorinated dibenzo-p-dioxins and dibenzofurans associated with pulp and paper mill discharge. Biomed Environ Mass Spectrom 14:443-447

82. Rappe C, Glas B, Kjeller LO, Kulp SE (1990) Levels of PCDDs and PCDFs in products and effluent from the Swedish pulp and paper industry and chloralkali process. Chemosphere 20:1701-1706

83. Swanson SE, Rappe C (1988) Emissions of PCDDs and PCDFs from the pulp industry. Chemosphere 17:681-69

84. Tu LK, Wu YL, Wang LC, Chang-Chien GP (2011) Distribution of polybrominated dibenzop-dioxins and dibenzofurans and polybrominated diphenyl ethers in a coal-fired power plant and two municipal solid waste incinerators. Aerosol Air Qual Res 11:596-615

85. Zook D, Rappe C (1994) Environmental sources, distribution, and fate. In: Schecter A (ed) Dioxins and health. Plenum, New York, pp 79-113

86. D'Silva K, Fernandes A, Rose M (2004) Brominated organic micropollutants-igniting the flame retardant issue. Crit Rev Environ Sci Technol 34:141-207

87. Ortuño N, Lundstedt S, Lundin L (2015) Emissions of PBDD/Fs, PCDD/Fs and PBDEs from flame-retarded high-impact polystyrene under thermal stress. Chemosphere 123:64-70

88. Olsman H, van Bavel B, Kalbin G, Pettersson A, Stenlund S, Strid Å, Engwall M (2002) Formation of dioxin-like compounds as photoproducts of decabrominated diphenyl ether (DEBDE) during UV-irradiation. Organohalogen Compd 58:41-44

89. Hayakawa K, Takatsuki H, Watanabe I, Sakai S-I (2004) Polybrominated diphenyl ethers (PBDEs), polybrominated dibenzo-p-dioxins/dibenzofurans (PBDD/Fs) and monobromopolychlorinated dibenzo-p-dioxins/dibenzofurans (MoBPXDD/Fs) in the atmosphere and bulk deposition in Kyoto, Japan. Chemosphere 57(5):343-356

90. UNEP (1999) Guidelines for the identification of PCBs and materials containing PCBs. United Nations Environment Programme Chemicals, Geneva

91. Agency for Toxic Substances, Disease Registry (ATSDR) (2014) ToxFAQs for Polychlorinated Biphenyls (PCBs). http://www.atsdr.cdc.gov/toxfaqs/tfacts17.pdf

92. De Voogt P, Brinkman UAT (1989) Production, properties and usage of polychlorinated biphenyls. In: Kimbrough RD, Jensen AA (eds) Halogenated biphenyls, terphenyls, naphthalenes, dibenzodioxins and related products. Elsevier, Amsterdam

93. Dyke PH, Foan C, Fiedler H (2003) PCB and PAH releases from power stations and waste incineration processes in the UK. Chemosphere 50:469-480

94. Sakai S, Hiraoka M, Takeda N, Shiozaki K (1996) Behavior of coplanar PCBs and PCNs in oxidative conditions of municipal waste incineration. Chemosphere 32:79-88

95. Grossman E (2013) Nonlegacy PCBs: Pigment manufacturing by-products get a second look. Environ Health Perspect 121:A87-A93

96. Marquenie JM, Reijnders J (1989) PCBs, an increasing concern for the marine environment. International Council for the Exploration of the Sea, Copenhagen, CM, 1989/N:12 
97. Dachs J, Bayona JM, Albaigés J (1997) Spatial distribution, vertical profiles and budget of organochlorine compounds in Western Mediterranean seawater. Mar Chem 57:313-324

98. Del Vento S, Dachs J (2002) Prediction of uptake dynamics of persistent organic pollutants by bacteria and phytoplankton. Environ Toxicol Chem 21:2099-2107

99. Wallberg P, Andersson A (2000) Transfer of carbon and a polychlorinated biphenyl through the pelagic microbial food web in a coastal ecosystem. Environ Toxicol Chem 19:827-835

100. Baker JE, Eisenreich SJ, Eadie BJ (1991) Sediment trap fluxes and benthic recycling of organic carbon, polycyclic aromatic hydrocarbons, and polychlorobiphenyl congeners in Lake Superior. Environ Sci Technol 25:500-509

101. Joiris CR, Overloop W (1991) PCBs and organochlorine pesticides in phytoplankton and zooplankton in the Indian sector of the Southern Ocean. Antarct Sci 3:371-377

102. Delbeke K, Joiris C (1988) Accumulation mechanisms and geographical distribution of PCBs in the North Sea. Oceanis 14:399-410

103. Galbán-Malagón CJ, Del Vento S, Berrojalbiz N, Ojeda M-J, Dachs J (2013) Polychlorinated biphenyls, hexachlorocyclohexanes and hexachlorobenzene in seawater and phytoplankton from the southern ocean (Weddell, South Scotia, and Bellingshausen Seas). Environ Sci Technol 47(11):5578-5587. doi:10.1021/es400030q

104. Hoekstra PF, O'Hara TM, Teixeira C, Backus S, Fisk AT, Muir DCG (2002) Spatial trends and bioaccumulation of organochlorine pollutants in marine zooplankton from the Alaskan and Canadian Arctic. Environ Toxicol Chem 21:575-583

105. Okumura Y, Yamashita Y, Kohno Y, Nagasaka H (2004) Historical trends of PCDD/Fs and CO-PCBs in a sediment core collected in Sendai Bay, Japan. Water Res 38(16):3511-3522

106. Wan Y, Hu J, Yang M, An L, An W, Jin X, Hattori T, Itoh M (2005) Characterization of trophic transfer for polychlorinated dibenzo-p-dioxins, dibenzofurans, non- and mono-ortho polychlorinated biphenyls in the marine food web of Bohai Bay, North China. Environ Sci Technol 39(8):2417-242

107. Peltonen H, Ruokojärvi P, Korhonen M, Kiviranta H, Flinkman J, Verta M (2014) PCDD/Fs, PCBs and PBDEs in zooplankton in the Baltic Sea - spatial and temporal shifts in the congener-specific concentrations. Chemosphere 114:172-180

108. Dachs J, Eisenreich SJ, Baker JE, Ko FC, Jeremiason JD (1999) Coupling of phytoplankton uptake and air-water exchange of persistent organic pollutants. Environ Sci Technol 33:3653-3660

109. Diaz E (2010) Evaluation of dioxins in shellfish from the Oakland Bay Site. http://www.atsdr. cdc.gov/HAC/pha/OaklandBayDioxins/OaklandBaySiteDioxinsHC07272010.pdf. Accessed 31 July 2015

110. Parera J, Ábalos M, Santos FJ, Galceran MT, Abad E (2013) Polychlorinated dibenzo-pdioxins, dibenzofurans, biphenyls, paraffins and polybrominated diphenyl ethers in marine fish species from Ebro River Delta (Spain). Chemosphere 93(3):499-505

111. Agramunt MC, Schuhmacher M, Hernandez JM, Domingo JL (2005) Levels of dioxins and furans in plasma of nonoccupationally exposed subjects living near a hazardous waste incinerator. J Expo Anal Environ Epidemiol 15(1):29-34

112. Gómara B, Bordajandi LR, Fernández MA, Herrero L, Abad E, Abalos M, Rivera J, González MJ (2005) Levels and trends of polychlorinated dibenzo-p-dioxins/furans (PCDD/Fs) and dioxin-like polychlorinated biphenyls (PCBs) in Spanish commercial fish and shellfish products, 1995-2003. J Agric Food Chem 5:8406-8413

113. Munschy C, Guiot N, Heas-Moisan K, Tixier C, Tronczynski J (2008) Polychlorinated dibenzo-p-dioxins and dibenzofurans (PCDD/Fs) in marine mussels from French coasts: levels, patterns and temporal trends from 1981 to 2005. Chemosphere 73:945-953

114. Malmvärn A, Zebühr Y, Jensen S, Kautsky L, Greyerz E, Nakano T, Asplund L (2005) Identification of polybrominated dibenzo-p-dioxins in blue mussels (Mytilus edulis) from the Baltic Sea. Environ Sci Technol 39:8235-8242 
115. Haglund P, Malmvarn A, Bergek S, Bignert A, Kautsky L, Nakano T, Wiberg K, Asplund L (2007) Brominated dibenzo-p-dioxins: a new class of marine toxins? Environ Sci Technol 41:3069-3074

116. Fernandes A, Dicks P, Mortimer D, Gem M, Smith F, Driffield M, White S, Rose M (2008) Brominated and chlorinated dioxins, PCBs and brominated flame retardants in Scottish shellfish: methodology, occurrence and human dietary exposure. Mol Nutr Food Res 52:238-249

117. Fernandes AR, Mortimer D, Gem M, Dicks P, Smith F, White S, Rose M (2009) Brominated dioxins (PBDD/Fs) and PBDEs in marine shellfish in the UK. Food Addit Contam 26:918-927

118. Van der Oost R, Beyer J, Vermeulen NPE (2003) Fish bioaccumulation and biomarkers in environmental risk assessment: a review. Environ Toxicol Pharmacol 13:57-149

119. Kiviranta H, Vartiainen T, Parmanne R, Hallikainen A, Koistinen J (2003) PCDD/Fs and PCBs in Baltic herring during the 1990s. Chemosphere 50:1201-1216

120. Karl H, Bladt A, Rottler H, Ludwigs R, Mathar W (2010) Temporal trends of PCDD, PCDF and PCB levels in muscle meat of herring from different fishing grounds of the Baltic Sea and actual data of different fish species from the Western Baltic Sea. Chemosphere 78:106-112

121. Miller A, Hedman JE, Nyberg E, Haglund P, Cousins IT, Wiberg K, Bignert A (2013) Temporal trends in dioxins (polychlorinated dibenzo-p-dioxin and dibenzofurans) and dioxin-like polychlorinated biphenyls in Baltic herring (Clupea harengus). Mar Pollut Bull 73:220-230

122. Airaksinen R, Hallikainen A, Rantakokko P, Ruokojärvi P, Vuorinen PJ, Parmanne R, Verta M, Mannio J, Kiviranta H (2014) Time trends and congener profiles of PCDD/Fs, PCBs, and PBDEs in Baltic herring off the coast of Finland during 1978-2009. Chemosphere 114:165-171

123. Haglund P, Lofstrand K, Malmvarn A, Bignert A, Asplund L (2010) Temporal variations of polybrominated dibenzo-p-dioxin and methoxylated diphenyl ether concentrations in fish revealing large differences in exposure and metabolic stability. Environ Sci Technol 44 (7):2466-2473

124. Ashizuka Y, Nakagawa R, Hori T, Yasutake D, Tobiishi K, Sasaki K (2008) Determination of brominated flame retardants and brominated dioxins in fish collected from three regions of Japan. Mol Nutr Food Res 52:273-283

125. Bordajandi LR, Martín I, Abad E, Rivera J, González MJ (2006) Organochlorine compounds (PCBs, PCDDs and PCDFs) in seafish and seafood from the Spanish Atlantic Southwest Coast. Chemosphere 64:1450-1457

126. Hickey JP, Batterman SA, Chernyak SM (2006) Trends of chlorinated organic contaminants in Great Lakes trout and walleye from 1970 to 1998. Arch Environ Contam Toxicol 50:97-110

127. Bhavsar SP, Awad E, Fletcher R, Hayton A, Somers KM, Kolic T, MacPherson K, Reiner EJ (2008) Temporal trends and spatial distribution of dioxins and furans in lake trout or lake whitefish from the Canadian Great Lakes. Chemosphere 73:S158-S165

128. Brown FR, Winkler J, Visita P, Dhaliwal J, Petreas M (2006) Levels of PBDEs, PCDDs, PCDFs, and coplanar PCBs in edible fish from California coastal waters. Chemosphere 64:276-286

129. Bishop CA, Brooks RJ, Carey JH, Ng P, Norstrom RJ, Lean DR (1991) The case for a causeeffect linkage between environmental contamination and development in eggs of the common snapping turtle (Chelydra S.serpentina) from Ontario, Canada. J Toxicol Environ Health 33:521-547

130. Bishop CA, Ng P, Norstrom RJ, Brooks RJ, Pettit KE (1996) Temporal and geographic variation of organochlorine residues in eggs of the common snapping turtle (Chelydra serpentina serpentina) (1981-1991) and comparisons to trends in the herring gull (Larus argentatus) in the Great Lakes basin in Ontario. Canada Arch Environ Contam Toxicol 31:512-524 
131. Bishop CA, Ng P, Pettit KE, Kennedy SW, Stegeman JJ, Norstrom RJ, Brooks RJ (1998) Environmental contamination and developmental abnormalities in eggs and hatchlings of the common snapping turtle (Chelydra serpentina serpentina) from the Great Lakes-St Lawrence River basin (1989-1991). Environ Pollut 10:143-156

132. Dabrowska H, Fisher SW, Estenik J, Kidekhel R, Stromberg P (2006) Polychlorinated biphenyl concentrations, congener profiles, and ratios in the fat tissue, eggs, and plasma of snapping turtles (Chelydra serpentina serpentina) from the Ohio Basin of Lake Erie. USA Arch Environ Contam Toxicol 51:270-286

133. De Solla SR, Fernie KJ (2004) Characterization of contaminants in snapping turtles (Chelydra serpentina serpentina) from Canadian Lake Erie Areas of Concern: St. Clair River, Detroit River, and Wheatley Harbour. Environ Pollut 132:101-112

134. De Solla SR, Bishop CA, Lickers H, Jock K (2001) Organochlorine pesticides, PCBs, dibenzodioxin, and furan concentrations in common snapping turtle eggs (Chelydra serpentina serpentina) in Akwesasne, Mohawk Territory, Ontario. Canada Arch Environ Contam Toxicol 40:410-417

135. De Solla SR, Fernie KJ, Letcher RJ, Chu SG, Drouillard KG, Shahmiri S (2007) Snapping turtles (Chelydra serpentina serpentina) as bioindicators in Canadian areas of concern in the Great Lakes Basin. 1. Polybrominated diphenyl ethers, polychlorinated biphenyls, and organochlorine pesticides in eggs. Environ Sci Technol 41:7252-7259

136. De Solla SR, Fernie KJ, Ashpole S (2008) Snapping turtles (Chelydra serpentina serpentina) as bioindicators in Canadian Areas of Concern in the Great Lakes Basin. II Changes in hatching success and hatchling deformities in relation to persistent organic pollutants. Environ Pollut 153:529-536

137. Ryan JJ, Lau BPY, Hardy JA, Stone WB, O'Keefe P, Gierthy JF (1986) 2,3,7,8-Tetrachlorodibenzo-p-dioxin and related dioxins and furans in snapping turtle (Chelydra serpentina serpentina) tissues from the upper St. Lawrence River. Chemosphere 15:537-548

138. Stone W, Kiviat E, Butkas SA (1980) Toxicants in snapping turtles. New York Fish Game J 27:39-50

139. Struger J, Elliott JE, Bishop CA, Obbard ME, Norstrom RJ, Weseloh DV, Simon M, Ng P (1993) Environmental contaminants in eggs of the common snapping turtle (Chelydra serpentina serpentina ) from the Great Lakes-St. Lawrence River basin of Ontario, Canada (1981, 1984). J Great Lakes Res 19:681-694

140. Eisenreich KM, Kelly SM, Rowe CL (2009) Latent mortality of juvenile snapping turtles from the upper Hudson River, New York, exposed maternally and via the diet to polychlorinated biphenyls (PCBs). Environ Sci Technol 43:6052-6057

141. Kelly SM, Eisenreich KM, Baker JE, Rowe CL (2008) Accumulation and maternal transfer of polychlorinated biphenyls in snapping turtles of the upper Hudson River, New York, USA. Environ Toxicol Chem 27:2565-2574

142. Bonin J, DesGranges JL, Bishop CA, Rodrigue J, Gendron A, Elliott JE (1995) Comparative study of contaminants in the mudpuppy (Amphibia) and common snapping turtle (Reptilia), St. Lawrence River. Canada Arch Environ Contam Toxicol 28:184-194

143. Hong C, Xiao J, Bush B, Shaw S (1998) Environmental occurrence and potential toxicity of planar, mono-, and di-ortho polychlorinated biphenyls in the biota. Chemosphere 36 (7):1637-1651

144. Basile ER, Avery HW, Bien WF, Keller JM (2011) Diamondback terrapins as indicator species of persistent organic pollutants: using Barnegat Bay, New Jersey as a case study. Chemosphere 82:137-144

145. Keller JM, Kucklick JR, Stamper MA, Harms CA, McClellan-Green PD (2004) Associations between organochlorine contaminant concentrations and clinical health parameters in loggerhead sea turtles from North Carolina. USA Environ Health Perspect 112:1074-1079

146. Storelli MM, Barone G, Marcotrigiano GO (2007) Polychlorinated biphenyls and other chlorinated organic contaminants in the tissues of Mediterranean loggerhead turtle Caretta caretta. Sci Total Environ 373:456-463 
147. Van Houtan KS, Hargrove SK, Balazs GH (2010) Land use, macroalgae, and a tumorforming disease in marine turtles. PLoS One 5(9), e12900. doi:10.1371/journal.pone. 0012900

148. Alava JJ, Keller JM, Wyneken J, Crowder L, Scott G, Kucklick JR (2011) Geographical variation of persistent organic pollutants in eggs of threatened loggerhead sea turtles (Caretta caretta) from southeastern United States. Environ Toxicol Chem 30(7):1677-1688

149. Keller JM, McClellan-Green PD, Kucklick JR, Keil DE, Peden-Adams MM (2006) Effects of organochlorine contaminants on loggerhead sea turtle immunity: comparison of a correlative field study and in vitro experiments. Environ Health Perspect 114:70-76

150. Orós J, González-Díaz OM, Monagas P (2009) High levels of polychlorinated biphenyls in tissues of Atlantic turtles stranded in the Canary Islands, Spain. Chemosphere 74:473-478

151. Ragland JM, Arendt MD, Kucklick JR, Keller JM (2011) Persistent organic pollutants in blood plasma of satellite-tracked adult male loggerhead sea turtles (Caretta caretta). Environ Toxicol Chem 30(7):1549-1556

152. Stewart KR, Keller JM, Templeton R, Kucklick JR, Johnson C (2011) Monitoring persistent organic pollutants in leatherback turtles (Dermochelys coriacea) confirms maternal transfer. Mar Pollut Bull 62:1396-1409

153. Camacho M, Boada LD, Orós J, López P, Zumbado M, Almeida-González M, Luzardo OP (2014) Monitoring organic and inorganic pollutants in juvenile live sea turtles: results from a study of Chelonia mydas and Eretmochelys imbricata in Cape Verde. Sci Total Environ 481:303-310

154. Hermanussen S, Limpus CJ, Paepke O, Connell DW, Gaus C (2006) Foraging habitat contamination influences green sea turtle $\mathrm{PCDD} / \mathrm{F}$ exposure. Organohalogen Compd 68:592-595

155. Braune BM, Simon M (2003) Dioxins, furans, and non-ortho PCBs in Canadian Arctic seabirds. Environ Sci Technol 37:3071-3077

156. Braune BM, Mallory ML, Butt CM, Mabury SA, Muir DC (2010) Persistent halogenated organic contaminants and mercury in northern fulmars (Fulmarus glacialis) from the Canadian Arctic. Environ Pollut 158(12):3513-3519

157. Braune BM, Mallory ML, Gilchrist HG, Letcher RJ, Drouillard KG (2007) Levels and trends of organochlorines and brominated flame retardants in ivory gull eggs from the Canadian Arctic, 1976 to 2004. Sci Total Environ 378(3):403-417

158. Giesy JP, Ludwig JP, Tillitt DE (1994) Dioxins, dibenzofurans, PCBs and colonial, fisheating water birds. In: Schecter A (ed) Dioxins health. Springer, New York pp 249-307

159. Henny CJ, Ganusevich SA, Ward FP, Meyburg STR (1994) Organochlorine pesticides, chlorinated dioxins and furans, and PCBs in peregrine falcon (Falco perigrinus) eggs from the Kola Peninsula, Russia. In: Meyburg BU, Chancellor RD (eds) Raptor conservation today: proceedings of the IV world conference on birds of prey and owls. Pica, Berlin, pp 739-748

160. De Wit CA, Järnberg UG, Asplund LT, Jansson B, Olsson M, Odsjö T, Lindstedt IL, Andersson Ö, Bergek S, Hjelt M, Appe C, Jansson A, Nygren M (1994) The Swedish dioxin survey: summary of results from $\mathrm{PCDD} / \mathrm{F}$ and coplanar $\mathrm{PCB}$ analyses in biota. Organohalogen Compd 20:47-50

161. Corsolini S, Borghesi N, Schiamone A, Focardi S (2007) Polybrominated diphenyl ethers, polychlorinated dibenzo-dioxins, -furans, and -biphenyls in three species of Antarctic penguins. Environ Sci Pollut Res 14:421-429

162. Custer CM, Custer TW, Dummer PM (2010) Patterns of organic contaminants in eggs of an insectivorous, an omnivorous, and a piscivorous bird nesting on the Hudson River, New York, USA. Environ Toxicol Chem 29:2286-2296

163. Seston RM, Giesy JP, Fredricks TB, Tazelaar DL, Coefield SJ, Bradley PW, Roark SA, Newsted JL, Kay DP, Zwiernik MJ (2012) Dietary- and tissue-based exposure of belted kingfisher to PCDFs and PCDDs in the Tittabawassee River floodplain, Midland, MI, USA. Environ Toxicol Chem 31:1158-1168 
164. Senthil Kumar K, Kannan K, Giesy J, Masunaga S (2002) Distribution and elimination of polychlorinated dibenzo-p-dioxins, dibenzofurans, biphenyls, and p, $\mathrm{p}^{\prime}$-DDE in tissues of bald eagles from the upper peninsula of Michigan. Environ Sci Technol 36:2789-2796

165. Henschel, D. S., 1993. LD50 and teratogenicity studies of the effects of TCDD on chicken embryos. In: Society of Environmental Toxicology and Chemistry Annual Meeting, Huston, Texas, 280.

166. Tillitt DE, Ankley GT, Giesy JP, Ludwig JP, Kurita-Matsuba H, Weseloh DV, Ross PS, Bishop CA, Sileo L, Stromborg KL, Larson J, Kubiak TJ (1992) Polychlorinated biphenyl residues and egg mortality in double-crested cormorants from the Great Lakes. Environ Toxicol Chem 11:1281-1288

167. Elliott JE, Wilson LK, Langelier KW, Norstrom RJ (1996) Bald eagle mortality and chlorinated hydrocarbon contaminants in livers from British Columbia, Canada, 1989-1994. Environ Pollut 94:9-18

168. Elliott JE, Harris ML, Wilson LK, Whitehead PE, Norstrom RJ (2001) Monitoring temporal and spatial trends in polychlorinated dibenzo- $p$-dioxins (PCDDs) and dibenzofurans (PCDFs) in eggs of great blue heron (Ardea herodias) on the coast of Bristh Columbia, Canada, 1983-1998. Ambio 30:416-428

169. Henny CJ, Kaiser JL, Grove RA, Bentley VR, Elliott JE (2003) Biomagnification factors (fish to osprey eggs from Wilamette River, Oregon, U.S.A.) for PCDDs, PCDFs, PCBs, and OC pesticides. Environ Monit Assess 84:275-315

170. Henny CJ, Kaiser JL, Grove RA (2009) PCDDs, PCDFs, PCBs, OC pesticides and mercury in fish and osprey eggs from Willamette River, Oregon (1993, 2001 and 2006) with calculated biomagnification factors. Ecotoxicology 18:151-173

171. Ryckman DP, Weseloh DV, Hamr P, Fox GA, Collins B, Ewins PJ, Norstrom RJ (1998) Spatial and temporal trends in organochlorine contamination and bill deformities in doublecrested cormorants (Phalacrocorax auritus) from the Canadian Great Lakes. Environ Monit Assess 53:169-195

172. Tillitt DE, Kubiak TJ, Ankley GT, Giesy JP (1993) Dioxin-like toxic potency in Forster's tern eggs from Green Bay, Lake Michigan, North America. Chemosphere 26:2079-2084

173. Kubiak TJ, Harris HJ, Smith LM, Schwartz T, Stalling DI, Trick JA, Sileo L, Docherty D, Erdman TC (1989) Microcontaminants and reproductive impairment of the Forster's tern on Green Bay, Lake Michigan-1983. Arch Environ Contam Toxicol 18:706-727

174. Jiménez B, Merino R, Abad E, Rivera J, Olie K (2007) Evaluation of organochlorine compounds (PCDDs, PCDFs, PCBs and DDTs) in two raptor species inhabiting a Mediterranean Island in Spain. Environ Sci Pollut Res 14(Special Issue 1):61-68

175. Wiemeyer SN, Lamont TJ, Bunck CN, Sindelar CR, Gramlich FJ, Fraser JD, Byrd MA (1984) Organochlorine pesticide, polychlorobiphenyl, and mercury residues in bald eagle eggs - 1969-1979 - and their relationships to shell thinning and reproduction. Arch Environ Contam Toxicol 13:529-549

176. Morales L, Martrat MG, Olmos J, Parera J, Vicente J, Bertolero A, Ãbalos M, Lacorte S, Santos FJ, Abad E (2012) Persistent organic pollutants in gull eggs of two species (Larus michahellis and Larus audouinii) from the Ebro delta Natural Park. Chemosphere 88 (11):1306-1316

177. Schröter- Kermani C, Schmolz E, Herrmann T, Päpke O (2005) PCDD, PCDF, and Dioxinlike PCB in herring gull eggs from the North Sea and Baltic Sea: levels, patterns and, temporal trends. Organohalogen Compd 67:1295-1299

178. Bignert A, Danielsson S, Faxneld S, Miller A, Nyberg E, Berger U, Borg H, Eriksson U, Holm K, Nylund K, Egebäck A-L, Haglund P (2013) Comments concerning the National Swedish Contaminant Monitoring Programme in marine biota. https://www.nrm.se/down load/18.3688e97313f58cd832059a0/1376578049930/Marinarapporten \pm 2013 .pdf. Accessed 31 July 2015

179. Pastor D, Ruiz X, Barceló D, Albaigés J (1995) Dioxins, furans and Ahh-active PCB congeners in eggs of two gull species from the Western Mediterranean. Chemosphere $31: 3397-3411$ 
180. Senthil Kumar K, Iseki N, Hayama S, Nakanishi J, Masunaga S (2002) Polychlorinated dibenzo-p-dioxins, dibenzofurans, and dioxin-like polychlorinated biphenyls in livers of birds from Japan. Arch Environ Contam Toxicol 42:244-255

181. Choi JW, Matsuda M, Kawano M, Wakimoto T, Iseki N, Masunaga S, Hayama S, Watanuki Y (2001) Chlorinated persistent organic pollutants in black-tailed gulls (Larus crassirostris) from Hokkaido, Japan. Chemosphere 44:1375-1382

182. Guruge KS, Tanabe S (1997) Congener specific accumulation and toxic assessment of polychlorinated biphenyls in common cormorants, Phalacrocorax carbo, from Lake Biwa. Japan Environ Pollut 96:425-433

183. Kunisue T, Nakaishi S, Oka N, Sato F, Tsurimi M, Tanabe S (2006) Dioxins and related compounds in albatrosses from the Torishima Island, Japan: accumulation features by growth stage and toxicological implications. Environ Sci Technol 40:6919-6927

184. Wu WZ, Zhang QH, Schramm K-W, Xu Y, Kettrup A (2000) Distribution, transformation, and long-term accumulation of polychlorinated dibenzo-p-dioxins and dibenzofurans in different tissues of fish and piscivorous birds. Ecotoxicol Environ Saf 46:252-257

185. Fang L, Zheng M, Zhang B, Gao L, Liu W, Zhao X (2007) Polychlorinated dibenzo-p-dioxins and dibenzofurans in eggs of eight avian species from Dongting Lake, China. Chemosphere 69:411-421

186. Choi JW, Matsuda M, Kawano M, Min BY, Wakimoto T (2001) Accumulation profiles of persistent organochlorines in waterbirds from an estuary in Korea. Arch Environ Contam Toxicol 41:353-363

187. Magera AM, Mills Flemming JE, Kaschner K, Christensen LB, Lotze HK (2013) Recovery trends in marine mammal populations. PLoS One 8, e77908

188. Giesy JP, Kannan K (2001) Global distribution of perfluorooctane sulfanate in wildlife. Environ Sci Technol 35:1339-1342

189. Hites RA (2004) Polybrominated diphenyl ethers in the environment and in people: a metaanalysis of concentrations. Environ Sci Technol 38(4):945-956

190. Shaw SD, Kannan K (2009) Polybrominated diphenyl ethers in marine ecosystems of the American continents: foresight from current knowledge. Rev Environ Health 24:157-229

191. Law RJ, Barry J, Barber JL, Bersuder P, Deaville R, Reid RJ, Brownlow A, Penrose R, Barnett J, Loveridge J, Smith B, Jepson PD (2012) Contaminants in cetaceans from UK waters: status as assessed within the Cetacean Strandings Investigation Programme from 1990 to 2008. Mar Pollut Bull 64:1485-1494

192. Mos L, Tabuchi M, Dangerfield N, Jeffries SJ, Koop BF, Ross PS (2007) Contaminantassociated disruption of vitamin $\mathrm{A}$ and its receptor (retinoic acid receptor a) in free-ranging harbour seals (Phoca vitulina). Aquat Toxicol 81:319-328

193. Schwacke LH, Zolman ES, Balmer BC, De Guise S, George RC, Hoguet J, Hohn A, Kucklick JR, Lamb S, Levin M, Litz J, McFee W, Place NJ, Townsend FI, Wells RS, Rowles TK (2011) Anaemia, hypothyroidism and immune suppression associated with polychlorinated biphenyl exposure in bottlenose dolphins (Tursiops truncatus). Proc R Soc Lond B Biol Sci 279:48-57

194. Rigét F, Bignert A, Braune B, Stow J, Wilson S (2010) Temporal trends of legacy POPs in Arctic biota, an update. Sci Total Environ 408(15):2874-2884

195. Riget F, Vikelsoe J, Dietz R (2005) Levels and temporal trends of PCDD/PCDFs and non-ortho PCBs in ringed seals from East Greenland. Mar Pollut Bull 50:1523-1529

196. Hoguet J, Keller JM, Reiner JL, Kucklick JR, Bryan CE, Moors AJ, Pugh RS, Becker PR (2013) Spatial and temporal trends of persistent organic pollutants and mercury in beluga whales (Delphinapterus leucas) from Alaska. Sci Total Environ 449:285-294

197. Dietz R, Rigét FF, Sonne C, Born EW, Bechshøft T, McKinney MA, Letcher RJ (2013) Three decades (1983-2010) of contaminant trends in East Greenland polar bears (Ursus maritimus). Part 1: legacy organochlorine contaminants. Environ Int 59:485-493 
198. McKinney MA, Peacock E, Letcher RJ (2009) Sea ice-associated diet change increases the levels of chlorinated and brominated contaminants in polar bears. Environ Sci Technol 43:4334-4339

199. McKinney MA, Stirling I, Lunn NJ, Peacock E, Letcher RJ (2010) The role of diet on longterm concentration and pattern trends of brominated and chlorinated contaminants in western Hudson Bay polar bears, 1991-2007. Sci Total Environ 408(24):6210-6222

200. McKinney MA, Letcher RJ, Aars J, Born EW, Branigan M, Dietz R, Evans TJ, Gabrielsen GW, Muir DCG, Peacock E, Sonne C (2011) Regional contamination versus regional dietary differences: understanding geographic variation in brominated and chlorinated contaminant levels in polar bears. Environ Sci Technol 45(3):896-902

201. McKinney MA, Letcher RJ, Aars J, Born EW, Branigan M, Dietz R, Evans TJ, Gabrielsen GW, Peacock E, Sonne C (2011) Flame retardants and legacy contaminants in polar bears from Alaska, Canada, East Greenland and Svalbard, 2005-2008. Environ Int 37(2):365-374

202. McKinney MA, Pedro S, Dietz R, Sonne C, Fisk AT, Roy D, Jenssen BM, Letcher RJ (2015) A review of ecological impacts of global climate change on persistent organic pollutant and mercury pathways and exposures in arctic marine ecosystems. Curr Zool 61(4):617-628

203. McKinney MA, Iverson SJ, Fisk AT, Sonne C, Rigét FF, Letcher RJ, Arts MT, Born EW, Rosing-Asvid A, Dietz R (2013) Global change effects on the long-term feeding ecology and contaminant exposures of East Greenland polar bears. Global Change Biol 19(8):2360-2372. doi: $10.1111 / \mathrm{gcb} .12241$

204. Schiavone A, Corsolini S, Borghesi N, Focardi S (2009) Contamination profiles of selected $\mathrm{PCB}$ congeners, chlorinated pesticides, $\mathrm{PCDD} / \mathrm{Fs}$ in Antarctic fur seal pups and penguin eggs. Chemosphere 76:264-269

205. Corsolini S, Kannan K, Imagawa T, Focardi S, Giesy JP (2002) Polychloronaphthalenes and other dioxin-like compounds in arctic and antarctic marine food webs. Environ Sci Technol 36:3490-3496

206. Oehme M, Schlabach M, Boyd I (1995) Polychlorinated dibenzo-p-dioxins, dibenzofurans and coplanar biphenyls in Anarctic fur seal blubber. Ambio 24(1):41-46

207. Lake C, Lake J, Haebler R, McKinney R, Boothman W, Sadove S (1995) Contaminant levels in harbor seals from the northeastern United States. Arch Environ Contam Toxicol 29:128-134

208. Gaskin DE, Frank R, Holdrinet M, Ishida K, Walton CJ, Smith M (1973) Mercury, DDT, and PCB in harbour seals (Phoca vitulina) from the Bay of Fundy and Gulf of Maine. J Fish Res Board Canada 30:471-475

209. Blomkvist G, Roos A, Jensen S, Bignert A, Olsson M (1992) Concentrations of $\sum D D T$ and PCB in seals from Swedish and Scottish waters. Ambio 21(8):539-545

210. Raach M, Lebeuf M, Pelletier E (2011) PBDEs and PCBs in the liver of the St Lawrence Estuary beluga (Delphinapterus leucas): a comparison of levels and temporal trends with the blubber. J Environ Monit 13:649-656

211. Kucklick J, Schwacke L, Wells R, Hohn A, Guichard A, Yordy J, Hansen L, Zolman E, Wilson R, Litz J, Nowacek D, Rowles T, Pugh R, Balmer B, Sinclair C, Rosel P (2011) Bottlenose dolphins as indicators of persistent organic pollutants in the western North Atlantic Ocean and northern Gulf of Mexico. Environ Sci Technol 45:4270-4277

212. She J, Petreas M, Winkler J, Visita P, McKinney M, Jones R, Kopec AD (2000) Harbor seals as indicators of halogenated contaminants in San Francisco Bay. Organohalogen Compd 49:422-425

213. Storelli MM, Barone G, Giacominelli-Stuffler R, Marcotrigiano GO (2012) Contamination by polychlorinated biphenyls (PCBs) in striped dolphins (Stenella coeruleoalba) from the Southeastern Mediterranean Sea. Environ Monit Assess 184:5797-5805

214. Imaeda D, Kunisue T, Ochi Y, Iwata H, Tsydenova OV, Takahashi S, Amano M, Petrov EA, Batoev VB, Tanabe S (2009) Accumulation features and temporal trends of PCDDs, PCDFs and PCBs in Baikal seals (Pusa sibirica). Environ Pollut 157:737-747

215. Moon HB, Choi HG, An YR, Park KJ, Choi SG, Moon DY, Kannan K (2010) Contamination status and accumulation features of PCDDs, PCDFs and dioxin-like PCBs in finless porpoises (Neophocaena phocaenoides) from Korean coastal waters. J Hazard Mater 183:799-805 
216. Moon H-B, Kannan K, Choi H-G, An Y-R, Choi S-G, Park J-Y, Kim Z-G (2010) Concentrations and accumulation features of PCDDs, PCDFs and dioxin-like PCBs in cetaceans from Korean coastal waters. Chemosphere 79:733-739

217. Yang F, Zhang Q, Xu Y, Jiang G, Wang Y, Wing D (2008) Preliminary hazard assessment of polychlorinated biphenyls, polybrominated diphenyl ethers, and polychlorinated dibenzo-pdioxins and dibenzofurans to Yangtze finless porpoises in Dongting Lake, China. Environ Toxicol Chem 27(4):991-996

218. Noel M, Barrett-Lennard L, Guinet C, Dangerfield N, Ross PS (2009) Persistent organic pollutants (POPs) in killer whales (Orcinus orca) from the Crozet Archipelago, southern Indian Ocean. Mar Environ Res 68:196-202

219. Wang D, Atkinson S, Hoover-Miller A, Lee S-E, Li QX (2007) Organochlorines in harbor seal (Phoca vitulina) tissues from the northern Gulf of Alaska. Environ Pollut 146:268-280

220. Wang D, Atkinson S, Hoove-Miller A, Li QX (2007) Polychlorinated naphthalenes and coplanar polychlorinated biphenyls in tissues of harbor seals (Phoca vitulina) from the northern Gulf of Alaska. Chemosphere 67:2044-2057

221. Lopez J, Boyd D, Ylitalo GM, Littnan C, Pearce RW (2012) Persistent organic pollutants in the endangered Hawaiian monk seal (Monachus schauinslandi) from the main Hawaiian Islands. Mar Pollut Bull 64:2588-2598

222. Weijs L, Tibax D, Roach AC, Manning TM, Chapman JC, Edge K, Blust R, Covaci A (2013) Assessing levels of halogenated organic compounds in mass-stranded long-finned pilot whales (Globicephala melas) from Australia. Sci Total Environ 461-462:117-125

223. Donkin P, Mann SV, Hamilton EI (1981) Polychlorinated biphenyl, DDT, and dieldrin residues in gray seal (Halichoerus grypus) males, females, and mother-fetus pairs sampled at the Farne Islands, England, during the breeding season. Sci Total Environ 19:121-142

224. Greig DJ, Ylitalo GM, Hall AJ, Fauquier DA, Gulland FMD (2007) Transplacental transfer of organochlorines in California sea lions (Zalophus californianus). Environ Toxicol Chem 26 (1):37-44

225. Wang D, Atkinson S, Hoover-Miller A, Shelver WL, Li QX (2012) Organic halogenated contaminants in mother-fetus pairs of harbor seals (Phoca vitulina richardii) from Alaska, 2000-2002. J Hazard Mater 223-224:72-78

226. Debier C, Pomeroy PP, Dupont C, Joiris C, Comblin V, Le Boulengé E, Larondelle Y, Thomé J-P (2003) Dynamics of PCB transfer from mother to pup during lactation in UK grey seals Halichoerus grypus: differences in PCB profile between compartments of transfer and changes during the lactation period. Mar Ecol Prog Ser 247:249-256

227. Vanden Berghe M, Weijs L, Habran S, Das K, Cl B, J-Fo R, Pomeroy P, Covaci A, Debier C (2012) Selective transfer of persistent organic pollutants and their metabolites in grey seals during lactation. Environ Int 46:6-15

228. Colborn T (1998) Building scientific consensus on endocrine disruptors. Environ Toxicol Chem 17:1-2

229. Sexton K, Hattis D (2007) Assessing cumulative health risks from exposure to environmental mixtures-three fundamental questions. Environ Health Perspect 115(5):825-832

230. Boas M, Feldt-Rasmussen U, Skakkebaek NE, Main KM (2006) Environmental chemicals and thyroid function. Eur J Endocrinol 154(5):599-611

231. Brown SB, Adams BA, Cyr DG, Eales JG (2004) Contaminant effects on the teleost fish thyroid. Environ Toxicol Chem 23:1680-1701

232. Ishihara A, Sawatsubashi S, Yamauchi K (2003) Endocrine disrupting chemicals: interference of thyroid hormone binding to transthyretins and to thyroid hormone receptors. Mol Cell Endocrinol 199:105-117

233. Brar NK, Waggoner C, Reyes JA, Fairey R, Kelley KM (2010) Evidence for thyroid endocrine disruption in wild fish in San Francisco Bay, California, USA. Relationships to contaminant exposures. Aquat Toxicol 96:203-215

234. Verreault J, Helgason LB, Gabrielsen GW, Dam M, Braune BM (2013) Contrasting retinoid and thyroid hormone status in differentially-contaminated northern fulmar colonies from the Canadian Arctic, Svalbard and the Faroe Islands. Environ Int 52:29-40 
235. Janz DM, Bellward GD (1996) In ovo 2,3,7,8-tetrachlorodibenzo-p-dioxin exposure in three avian species. 1. Effects on thyroid hormones and growth during the perinatal period. Toxicol Appl Pharmacol 139:281-291

236. Braathen M, Derocher AE, Wiig O, Sørmo EG, Lie E, Skaare JU, Jenssen BM (2004) Relationships between PCBs and thyroid hormones and retinol in female and male polar bears. Environ Health Perspect 112(8):826-833

237. Haave M, Ropstad E, Derocher AE, Lie E, Dahl E, Wiig Ø, Skaare JU, Jenssen B (2003) Polychlorinated biphenyls and reproductive hormones in female polar bears at Svalbard. Environ Health Perspect 111(4):431-436

238. Sonne C, Dietz R, Born EW, Rigét FF, Kirkegaard M, Hyldstrup L, Letcher RJ, Muir DCG (2004) Is bone mineral composition disrupted by organochlorines in East Greenland polar bears (Ursus maritimus)? Environ Health Perspect 112:1711-1716

239. Tenenbaum DJ (2004) POPs in polar bears: organochlorines affect bone density. Environ Health Perspect 112:A1011

240. Aulerich RJ, Ringer RK (1977) Current status of PCB toxicity to mink, and effect on their reproduction. Arch Environ Contam Toxicol 6:279-292

241. Jensen S, Jansson B (1976) Anthropogenic substances in seal from the Baltic: methyl sulfone metabolites of PCB and DDE. Ambio 5:257-260

242. Yu L, Liu C, Chen Q, Zhou B (2014) Endocrine disruption and reproduction impairment in zebrafish after long-term exposure to DE-71. Environ Toxicol Chem 33:1354-1362

243. Tata JR, Smith DF (1979) Vitellogenesis: a versatile model for hormonal regulation of gene expression. Recent Prog Horm Res 35:47-95

244. Mommsen TP, Walsh PJ (1988) Vitellogenesis and oocyte assembly. In: Hoar WS, Randall DJ (eds) Fish physiology. Academic, New York, pp 347-406

245. Cheek AO, Brouwer TH, Carroll S, Manning S, McLachlan JA, Brouwer M (2001) Experimental evaluation of vitellogenin as a predictive biomarker for reproductive disruption. Environ Health Perspect 109:681-690

246. Folmar LC, Gardner GR, Schreibman MP, Magliulo-Cepriano L, Mills LJ, Zaroogian G, Gutjahr-Gobell R, Haebler R, Horowitz DB, Denslow ND (2001) Vitellogenin-induced pathology in male summer flounder (Paralichthys dentatus). Aquat Toxicol 51:431-441

247. Kidd KA, Blanchfield PJ, Mills KH, Palace VP, Evans RE, Lazorchak JM, Flick RW (2007) Collapse of a fish population after exposure to a synthetic estrogen. Proc Natl Acad Sci U S A 104:8897-8901

248. Van den Belt K, Wester PW, Ven LVD, Verheyen R, Witters H (2002) Effects of ethynylestradiol on the reproductive physiology in zebrafish (Danio rerio): time dependency and reversibility. Environ Toxicol Chem 21:767-775

249. Helander B, Olsson A, Bignert A, Asplund L, Litzén K (2002) The role of DDE, PCB, coplanar PCB and eggshell parameters for reproduction in the white-tailed sea eagle (Haliaeetus albicilla) in Sweden. Ambio 31:386-403

250. Helberg M, Bustnes JO, Erikstad KE, Kristiansen KO, Skaare JU (2005) Relationships between reproductive performance and organochlorine contaminants in great black-backed gulls (Larus marinus). Environ Pollut 134:475-483

251. Helle E, Olssen M, Jensen S (1976) PCB levels correlated with pathological changes in seal uteri. Ambio 5(5-6):261-263

252. Kierkegaard A, Bignert A, Sellström U, Olsson M, Asplund L, Jansson B, Wit CAD (2004) Polybrominated diphenyl ethers (PBDEs) and their methoxylated derivatives in pike from Swedish waters with emphasis on temporal trends, 1967-2000. Environ Pollut 130:187-198

253. Bergman $\AA$, Olsson M (1985) Pathology of Baltic grey seal and ringed seal females with special reference to adrenocortical hyperplasia: is environmental pollution the cause of a widely distributed disease syndrome? Finn Game Res 44:47-6

254. Harding KC, Härkönen TJ (1999) Development in the Baltic grey seal (Halichoerus grypus) and ringed seal (Phoca hispida) populations during the 20th century. Ambio 28:619-627 
255. Bergman A (2007) Pathological changes in seals in Swedish waters: the relation to environmental pollution, tendencies during a 25 -year period. Doctoral thesis. Faculty of Veterinary medicine and animal science: University of Agricultural Science, Sweden

256. Bredhult C, Backlin B-M, Bignert A, Olovsson M (2008) Study of the relation between the incidence of uterine leiomyomas and the concentrations of PCB and DDT in Baltic gray seals. Reprod Toxicol 25:247-255

257. Vos JG, Driel-Grootenhuis LV (1972) PCB-induced suppression of the humoral and cellmediated immunity in guinea pigs. Sci Total Environ 1:289-302

258. Vos JG, Moore JA, Zinkl JG (1973) Effect of 2, 3, 7, 8-tetrachlorodibenzo-p-dioxin on the immune system of laboratory animals. Environ Health Perspect 5:149-162

259. Jepson PD, Bennett PM, Allchin CR, Law RJ, Kuiken T, Baker JR, Rogan E, Kirkwood JK (1999) Investigating potential associations between chronic exposure to polychlorinated biphenyls and infectious disease mortality in harbour porpoises from England and Wales. Sci Total Environ 243-244:339-348

260. Kannan K, Tanabe S, Borrell A, Aguilar A, Focardi S, Tatsukawa R (1993) Isomer-specific analysis and toxic evaluation of polychlorinated biphenyls in striped dolphins affected by an epizootic in the western Mediterranean Sea. Arch Environ Contam Toxicol 25:227-233

261. Zhou J, Zhu X-S, Cai Z-H (2009) Endocrine disruptors: an overview and discussion on issues surrounding their impact on marine animals. J Mar Animals Ecol 2(2):7-17

262. Mahy BWJ, Barrett T, Evans S, Anderson EC, Bostock CJ (1988) Characterization of a seal morbillivirus. Nature 336:115-116

263. Duignan PJ, Sadove S, Saliki JT, Geraci JR (1993) Phocine distemper in harbor seals (Phoca vitulina) from Long Island, New York. J Wildl Dis 29(3):465-469

264. Duignan PJ, Saliki JT, St. Aubin DJ, Early G, Sadove S, House JA, Kovacs KM, Geraci JR (1995) Epizootiology of morbillibirus infection in North American harbor seals (Phoca vitulina) and gray seals (Halichoerus grypous). J Wildl Dis 31(4):491-501

265. Garron M, McNulty S (2008) NOAA fisheries service northeast region marine mammal stranding program: 2007 summary. In: Northeast Region Stranding Network Conference. Providence, RI

266. Scott GP, Burn DM, Hansen LJ (1988) The dolphin dieoff: long-term effects and recovery of the population. In: CEANS '88. Proceedings of a partnership of marine interests. Oct. 31Nov. 2 1988, IEEE, Baltimore, MD, USA, pp 819-823

267. Duignan PJ, House C, Odell DK, Wells RS, Hansen LJ, Walsh MT, St. Aubin DJ, Rima BK, Geraci JR (1996) Morbillivirus infection in bottlenose dolphins: evidence for recurrent epizootics in the western Atlantic and Gulf of Mexico. Mar Mamm Sci 12(4):499-515

268. Van Loveren H, Ross PS, Osterhaus ADME, Vos JG (2000) Contaminant-induced immunosuppression and mass mortalities among harbor seals. Toxicol Lett 112-113:319-324

269. Murk AJ, Leonards PE, van Hattum B, Luit R, van der Weiden ME, Smit M (1998) Application of biomarkers for exposure and effect of polyhalogenated aromatic hydrocarbons in naturally exposed European otters (Lutra lutra). Environ Toxicol Pharmacol 6:91-102

270. Smit MD, Leonards PEG, Murk AJ, Jongh AD, Hattum BV (1996) Development of otterbased quality objectives for PCBs. Institute for Environmental Studies, De Boelelaan

271. Beckmen KB, Blake JE, Ylitalo GM, Stott JL, O’Hara TM (2003) Organochlorine contaminant exposure and associations with hematological and humoral immune functional assays with dam age as a factor in free-ranging northern fur seal pups (Callorhinus ursinus). Mar Pollut Bull 46:594-606

272. Lie E, Larsen HJS, Larsen S, Johansen GM, Derocher AE, Lunn NJ, Norstrom RJ, Wiig O, Skaare JU (2004) Does high organochlorine (OC) exposure impair the resistance to infection in polar bears (Ursus maritimus)? Part I: effect of OC's on the humoral immunity. J Toxicol Environ Health 67(Part A):555-582

273. De Wit CA, Fisk AT, Muir DCG (2005) Effects of persistent organic pollutants (POPs) in arctic wildlife. Organohalogen Compd 67:962-964 
274. Yap X, Deaville R, Perkins MW, Penrose R, Law RJ, Jepson PD (2012) Investigating links between polychlorinated biphenyl (PCB) exposure and thymic involution and thymic cysts in harbour porpoises (Phocoena phocoena). Mar Pollut Bull 64(10):2168-2176

275. Shaw SD, Brenner D, Hong C-S, Bush B, Shopp GM (1999) Low-level exposure to PCBs is associated with immune and endocrine disruption in neonatal harbor seals (Phoca vitulina) from the California coast. Organohalogen Compd 42:11-14

276. Simms W, Jeffries S, Ikonomou M, Ross PS (2000) Contaminant-related disruption of vitamin A dynamics in free-ranging harbor seal (Phoca vitulina) pups from British Columbia, Canada, and Washington State, USA. Environ Toxicol Chem 19(11):2844-2849

277. Noyes PD, McElwee MK, Miller HD, Clark BW, Van Tiem LA, Walcott KC, Erwin KN, Levin ED (2009) The toxicology of climate change: environmental contaminants in a warming world. Environ Int 35:971-986

278. Rijnsdorp AD, Vethaak AD (1997) Changes in reproductive parameters of North Sea plaice and sole between 1960 and 1995. ICES C.M. 1997/U:14. International Council for the Exploration of the Sea, Copenhagen

279. Rhind SM (2009) Anthropogenic pollutants: a threat to ecosystem sustainability? Philos Trans R Soc B Biol Sci 364:3391-3401

280. Schipper J, Chanson JS, Chiozza F, Cox NA, Hoffmann M, Katariya V, Lamoreux J, Rodrigues ASL, Stuart SN, Temple HJ et al (2008) The status of the world's land and marine mammals: diversity, threat, and knowledge. Science 322:225-230

281. Gulland FMD, Hall AJ (2007) Is marine mammal health deteriorating? Trends in the reporting of marine mammal disease. Ecohealth 4:135-150

282. Bäcklin B-M, Moraeus C, Kauhala K, Isomursu M (2013) Pregnancy rates of the marine mammals-particular emphasis on Baltic grey and ringed seals. http://www.helcom.fi/Core\% 20Indicators/HELCOM-CoreIndicator-Pregnancy_rates_of_marine_mammals.pdf. Accessed 31 July 2015

283. Naito W, Murata M (2007) Evaluation of population-level ecological risks of dioxin-like polychlorinated biphenyl exposure to fish-eating birds in Tokyo Bay and its vicinity. Integr Environ Assess Manag 3:68-78

284. Van Bressem M-F, Raga JA, De Guardo G, Jepson PD, Duignan PJ, Siebert U, Barrett T, de Oliveira Santos MC, Moreno IB, Siciliano S, Aguilar A, Van Waerebeek K (2009) Emerging infectious diseases in cetaceans worldwide and the possible role of environmental stressors. Dis Aquat Org 86:143-157

285. IUCN Polar Bear Specialist Group (2015) Summary of polar bear population status per 2014. http://pbsg.npolar.no/en/status/status-table.html. Accessed 2 Dec 2015

286. Bromaghin JF, McDonald TL, Stirling I, Derocher AE, Richardson ES, Regehr EV, Douglas DC, Durner GM, Atwood T, Amstrup SC (2015) Polar bear population dynamics in the southern Beaufort Sea during a period of sea ice decline. Ecol Appl 25(3):634-651

287. Willams T (2014) After steep decline, signs of hope for worlds sea turtles. Yale Environ 360. http://e360.yale.edu/feature/after_steep_decline_signs_of_hope_for_worlds_sea_turtles/2831/. Accessed 2 Dec 2015

288. Aguirre AA, Lutz P (2004) Marine turtles as sentinels of ecosystem health: is fibropapillomatosis an indicator? Ecohealth 1(3):275-283

289. Arthur K, Limpus C, Balazs G, Capper A, Udy J, Shaw G, Keuper-Bennett U, Bennett P (2008) The exposure of green turtles (Chelonia mydas) to tumour promoting compounds produced by the cyanobacterium Lyngbya majuscula and their potential role in the aetiology of fibropapillomatosis. Harmful Algae 7(1):114-125

290. Shaffer SA, Tramblay Y, Weimerskirch H, Scott D, Thompson D, Sagar PM, Moller H, Taylor GA, Goley DG, Block BA, Costa DP (2006) Migratory shearwaters integrate oceanic resources across the Pacific Ocean in an endless summer. Proc Natl Acad Sci 103:12799-12802

291. Tanabe S (1985) Distribution, behavior and fate of PCBs in the marine environment. J Oceanogr Soc Jpn 41:358-370 